IZA DP No. 5964

Low-Skilled Immigrants and the U.S. Labor Market

Brian Duncan

Stephen J. Trejo

September 2011

Forschungsinstitut zur Zukunft der Arbeit Institute for the Study of Labor 


\title{
Low-Skilled Immigrants and the U.S. Labor Market
}

\author{
Brian Duncan \\ University of Colorado Denver \\ Stephen J. Trejo \\ University of Texas at Austin \\ and IZA
}

\section{Discussion Paper No. 5964 \\ September 2011}

\author{
IZA \\ P.O. Box 7240 \\ 53072 Bonn \\ Germany \\ Phone: +49-228-3894-0 \\ Fax: +49-228-3894-180 \\ E-mail: iza@iza.org
}

Any opinions expressed here are those of the author(s) and not those of IZA. Research published in this series may include views on policy, but the institute itself takes no institutional policy positions.

The Institute for the Study of Labor (IZA) in Bonn is a local and virtual international research center and a place of communication between science, politics and business. IZA is an independent nonprofit organization supported by Deutsche Post Foundation. The center is associated with the University of Bonn and offers a stimulating research environment through its international network, workshops and conferences, data service, project support, research visits and doctoral program. IZA engages in (i) original and internationally competitive research in all fields of labor economics, (ii) development of policy concepts, and (iii) dissemination of research results and concepts to the interested public.

IZA Discussion Papers often represent preliminary work and are circulated to encourage discussion. Citation of such a paper should account for its provisional character. A revised version may be available directly from the author. 
IZA Discussion Paper No. 5964

September 2011

\section{ABSTRACT}

\section{Low-Skilled Immigrants and the U.S. Labor Market}

Over the last several decades, two of the most significant developments in the U.S. labor market have been: (1) rising inequality, and (2) growth in both the size and the diversity of immigration flows. Because a large share of new immigrants arrive with very low levels of schooling, English proficiency, and other skills that have become increasingly important determinants of success in the U.S. labor market, an obvious concern is that such immigrants are a poor fit for the restructured American economy. In this chapter, we evaluate this concern by discussing evidence for the United States on three relevant topics: the labor market integration of immigrants, the socioeconomic attainment of the U.S.-born descendants of immigrants, and the impact of immigration on the wages and employment opportunities of native workers. We show that low-skilled immigrants have little trouble finding paid employment and that the wages they earn are commensurate with their skills. Overall, the U.S.-born second generation has achieved economic parity with mainstream society; for some Hispanic groups, however, this is not the case. Finally, we survey the pertinent academic literature and conclude that, on the whole, immigration to the United States has not had large adverse consequences for the labor market opportunities of native workers.

JEL Classification: J61, J62, J68

Keywords: immigrant labor, assimilation, generational progress

Corresponding author:

Stephen J. Trejo

Department of Economics

University of Texas at Austin

1 University Station C3100

Austin, TX 78712-0301

United States

E-mail: trejo@austin.utexas.edu

\footnotetext{
* This research was supported by NICHD grants R03HD050574 and R03HD066104 to Stephen Trejo and R24HD042849 to the Population Research Center at the University of Texas at Austin. The content is solely the responsibility of the authors and does not necessarily represent the official views of the NICHD or the NIH.
} 


\section{Introduction}

Over the last several decades, two of the most significant developments in the U.S. labor market have been: (1) rising inequality, and (2) growth in both the size and the diversity of immigration flows. Because a large share of new immigrants arrive with very low levels of schooling, English proficiency, and other skills that have become increasingly important determinants of success in the U.S. labor market, an obvious concern is that such immigrants are a poor fit for the restructured American economy. In this chapter, we evaluate this concern by discussing evidence for the United States on three relevant topics: the labor market integration of immigrants, the socioeconomic attainment of the U.S.-born descendants of immigrants, and the impact of immigration on the wages and employment opportunities of native workers.

The backdrop for resurgent U.S. immigration has been an economy in which earnings inequality and the labor market rewards to education and other indicators of worker skill have increased dramatically (Levy and Murnane 1992; Autor and Katz 1999). How have U.S. immigrants fared in the last few turbulent decades? In particular, how have recent shifts in the wage structure and other ongoing changes in the U.S. economy affected the large group of immigrants who arrive with little in the way of schooling or skills? In effect, these unskilled immigrants are swimming upstream against the predominant economic currents that have heightened the importance of education and cognitive ability. In the restructured U.S. labor market, what is the role of immigrants, in general, and of unskilled immigrants, in particular?

As noted by Raphael and Smolensky (2009b), rising immigration-particularly unskilled immigration—could potentially exacerbate U.S. poverty through two main channels. Because poverty rates are relatively high for immigrants (Chapman and Bernstein 2003; Sullivan and Zeigert 2008; Raphael and Smolensky 2009b), especially for recent arrivals and for less-skilled 
immigrants, an increased share of the population that is foreign-born has a direct or compositional effect that raises the overall U.S. poverty rate. In addition, to the extent that labor market competition with immigrants lowers the wages and employment rates of U.S.-born workers, immigration could have the indirect effect of raising poverty among U.S. natives. The evidence we review below sheds light on both the direct and indirect pathways through which immigration might affect poverty.

The chapter is organized as follows. In the next section, we discuss how immigrants perform in the U.S. labor market, with an emphasis on the fundamental role played by human capital. The following section presents a similar analysis for the U.S.-born descendants of immigrants, highlighting the diversity of immigrant backgrounds and the problems this can create for tracking the intergenerational progress of immigrant groups. The section after that provides a brief survey of the academic literature assessing the impact of U.S. immigration on the wages and employment opportunities of native workers, and a final section summarizes and concludes.

\section{Labor Market Integration of Immigrants}

How quickly and completely do immigrants adapt to the U.S. labor market? In this section, we discuss several key aspects of immigrant economic integration: the skills and human capital that immigrants bring to the labor market, the availability of jobs for immigrant workers, and the extent to which the earnings of these workers reflect their skills. Given the policy concerns that have been raised regarding low-skill immigrants, we focus particular attention on this group, and we also highlight importance differences by race/ethnicity.

To illustrate patterns of immigrant human capital and labor market outcomes, we pool 
microdata from the American Community Survey (ACS) for the years 2005, 2006, and 2007. For each of these years, the ACS data constitute a one percent sample of the U.S. population. Our analysis sample includes men ages 25-59 who do not reside in institutions. We exclude women in order to minimize biases arising from selective labor force participation, and we choose this age range so as to focus on men in their prime working years who likely have completed their formal schooling.

We distinguish individuals born in the United States (i.e., natives) from those born in another country. ${ }^{1}$ Within the foreign-born population, those born abroad of an American parent are treated as a separate nativity category, and remaining foreign-born individuals are split into “child immigrants” who arrived in the United States before the age of 16 and "adult immigrants” who arrived at age 16 or later. We make this latter distinction because immigrants who arrive as children, and who therefore acquire much of their education and all of their work experience in the United States and who are more likely to speak English fluently, experience greater economic success than immigrants who come as adults (Rumbaut 2004; Bleakley and Chin 2004).

Using answers to the questions regarding Hispanic origin and race, we assign each individual to one of five mutually exclusive and exhaustive racial/ethnic groups: Hispanic (of any race), and non-Hispanic white, black, Asian (including Native Hawaiian and Pacific Islander), and a residual “other race” category. Starting in 2000, the Census and ACS permit respondents to designate more than one race (Grieco and Cassidy 2001; del Pinal 2004). The

\footnotetext{
${ }^{1}$ Throughout this chapter, we use the term "immigrant” as synonymous with foreign-born individuals, in contrast to the official terminology used by the U.S. government in which immigrants are legal permanent residents, and other foreigners such as tourists, business travelers, and recent refugee arrivals are "nonimmigrant aliens.” The data analyzed here cannot make such distinctions among foreign-born individuals. Included within our "immigrant” sample are individuals born in Puerto Rico and other outlying areas of the United States. Although persons born in Puerto Rico are U.S. citizens and enjoy unfettered
} 
Hispanic origin question, however, still requires a single response. Our "other race” category includes any non-Hispanics who designated two or more major race groups, as well as those who identified with an “American Indian or Alaskan Native” group. Therefore, the non-Hispanic categories “white,” “black,” and “Asian” represent individuals who designated a single major race group. $^{2}$

Table 1 reports the distribution of our sample by nativity and race/ethnicity and shows sample sizes and average completed years of schooling for the relevant groups. ${ }^{3}$ About 80 recent of these men were born in the United States, one percent were born abroad of an American parent, and the remaining 19 percent of the sample is made up of immigrants, most of whom were at least age 16 when they arrived in the United States (15 percent of the total sample), but some arrived at a younger age (4 percent of the total sample). The ACS data provide large samples of all nativity groups, and sizeable samples remain even for particular racial/ethnic categories within nativity groups (see panel B of Table 1). In terms of race and ethnicity, immigrants are much more diverse than U.S. natives. Whereas 80 percent of the U.S.-born population is comprised of non-Hispanic whites, more than half of immigrants are Hispanic and another fifth are Asian.

Table 1 suggests important links between nativity, race/ethnicity, and skills. Overall, average years of education are lowest for adult immigrants (11.8 years) and highest for persons

mobility between the island and the U.S. mainland, such migrants encounter many of the same adjustment issues as other immigrants.

${ }^{2}$ In the 2000 Census, less than two percent of non-Hispanics designated more than one major race group (Jones and Symens Smith 2001). Consequently, our decision to include only those who report a single race in the white, black, and Asian race groups is unlikely to have much effect on the results.

${ }^{3}$ Beginning in 1990, the Census questions about educational attainment were changed to ask specifically about postsecondary degrees obtained rather than years of schooling, and the ACS education questions are modeled on those in the 2000 Census. We follow Jaeger's (1997) recommendations for how to construct a completed years of schooling variable from the revised education questions. 
either born in the United States (13.5 years) or born abroad of an American parent (13.9 years). Immigrants who arrived as children and potentially received some or all of their schooling in the United States possess an intermediate level of educational attainment (12.6 years). Within every nativity group, Hispanics have the lowest average schooling level (ranging from 9.7 years for Hispanic adult immigrants to 11.2 years for Hispanic child immigrants to 12.6 years for U.S.born Hispanics), so the educational deficit of immigrants in part reflects the heavy concentration of Hispanics in the foreign-born population. In contrast, non-Hispanic whites and Asians exhibit relatively high schooling levels within every nativity group.

In order to provide further detail on the substantial education differences that exist between nativity and racial/ethnic groups, Table 2 shows percentage distributions across four schooling levels. The lowest education category, which we will sometimes refer to as high school “dropouts,” consists of those who have completed fewer than 12 years of schooling. The next category, those with exactly 12 years of schooling, is dominated by high school graduates, but it also includes persons who completed twelfth grade but did not receive a diploma, as well as persons who completed high school by means of an equivalency exam such as the General Equivalency Diploma (GED). The education category for 13-15 years of schooling includes those with some college but not a bachelor's degree, and the highest education category represents those with at least a bachelor's degree.

Table 2 highlights the low educational attainment of many foreign-born men. ${ }^{4}$ Thirty percent of adult immigrants and 20 percent of child immigrants have less than 12 years of schooling, compared to only 8 percent of U.S.-born men and 6 percent of those born abroad of an American parent. Though not shown in Table 2, the contrast is even more striking for men

\footnotetext{
${ }^{4}$ Although Table 2 presents information only for men, the education distributions of women are similar.
} 
with less than 9 years of schooling: this group represents 21 percent of adult immigrants versus just 2 percent of U.S.-born men. Looking at this same phenomenon from a slightly different perspective, adult immigrants comprise only 15 percent of the overall sample of men in Table 2, but they make up 38 percent of the men with less than 12 years of schooling and 62 percent of the men with less than 9 years of schooling. Similarly, immigrants who arrived as children represent just 4 percent of the overall sample but 7 percent of those with less than 12 years of schooling and 8 percent of those with less than 9 years of schooling. Clearly, immigrants are disproportionately concentrated among U.S. workers with the lowest education levels.

At the same time, however, immigrants are well represented among U.S. workers with the highest education levels. For example, completion of a bachelor's degree is about equally common for adult immigrants (28 percent) as for U.S.-born men (29 percent), whereas a higher fraction of adult immigrants than U.S.-born men earn postgraduate degrees (13 percent versus 10 percent, though this education category is not separately identified in Table 2). Immigrants are overrepresented at the bottom and, to a lesser extent, the top of the U.S. educational distribution, and they are underrepresented in the middle (with 42 percent of adult immigrants and 54 percent of child immigrants, compared to 63 percent of U.S.-born men, completing 12-15 years of schooling).

Table 2 also documents the extensive variation in educational attainment by race/ethnicity within nativity groups. Among Hispanic adult immigrants, for example, almost half of these men possess less than 12 years of schooling and only 9 percent have completed a bachelor's degree. The educational distribution is reversed, however, among Asian adult immigrants, with just 9 percent being high school dropouts and 57 percent having graduated from college. The educational distribution of white immigrants is similar to that of Asian 
immigrants, whereas the distribution of black immigrants has more weight in the middle categories representing high school graduates and those with some college. The patterns of racial/ethnic differences in schooling for other nativity groups (i.e., child immigrants, those born abroad of an American parent, and U.S.-born men) are broadly similar to those for adult immigrant men, although the magnitudes of the differences are usually smaller, especially between Hispanics and non-Hispanics. Among U.S.-born men, however, the schooling advantage of Asians is even more remarkable; their college completion rate of 54 percent far exceeds the corresponding rates of 32 percent for Anglos, 20 percent for "other race" individuals, and 16 percent for Hispanic Americans and for African Americans.

\section{A. Employment}

How well has the U.S. labor market been able to absorb the large inflows of immigrants received in recent years, especially the immigrants from less developed countries who often arrive with little education and few skills? An important indicator of the answer to this question is the ease with which these immigrants find gainful employment in the United States. Therefore, we next compare the employment rates of foreign-born and U.S.-born men, focusing in particular on how these comparisons vary by education and by the amount of time immigrants have had to adjust to their new country of residence.

For the sample of men described above, Table 3 reports employment rates by nativity and education category. Here, the employment rate represents the percentage of men who were employed at any time during the twelve months preceding the survey date. Standard errors are shown in parentheses. Aggregating individuals from all education levels (i.e., see the far right column of Table 3), the overall male employment rates are similar across nativity groups, ranging from 90 percent for U.S.-born men to 92 percent for child immigrants to 93 percent for 
adult immigrants and for those born abroad of an American parent. Immigrant-native employment differences vary enormously by education level, however. Among high school dropouts, the employment rate of adult immigrants exceeds that of U.S.-born men by over 20 percentage points, whereas the corresponding employment advantage of adult immigrants falls to 5 percentage points among those with 12 years of schooling and disappears at higher education levels. This pattern arises because employment rates increase strongly with education for U.S.born men but not for adult immigrants. For other foreign-born men—child immigrants and those born abroad of an American parent- - the relationship between employment and schooling is positive but not as strong as for U.S.-born men. As a result, sizeable employment advantages (relative to U.S.-born men) also emerge in the lowest education category for these other foreignborn men (17 percentage points for child immigrants and 10 percentage points for those born abroad of an American parent).

An important lesson from Table 3 is that foreign-born men display high employment propensities, relative to U.S.-born men, among those with the lowest schooling levels (high school dropouts), and the magnitude of this immigrant employment advantage is striking. At other levels of schooling, foreign-born and U.S.-born men exhibit similar rates of employment. Are these patterns the spurious result of differences in the characteristics of foreign-born and U.S.-born men that are correlated with employment? To shed light on this issue, we use regression analysis to investigate the influence of observable factors on immigrant-native employment differences.

Table 4 reports the estimated coefficients from least squares regressions in which the dependent variable is a dummy identifying individuals who were employed at any time during 
the twelve months preceding the survey date. ${ }^{5}$ Given our special interest in low-skill immigrants, and also to examine in greater detail the intriguing educational pattern observed in Table 3, we split the sample into two education groups-men with less than 12 years of schooling and those with at least 12 years - and we run separate regressions for each group. All regressions include controls for age, geographic location, and survey year. ${ }^{6}$ The regressions for men with 12 or more years of schooling also include dummies identifying individuals with 13-15 and 16 or more years of schooling (with individuals possessing exactly 12 years of schooling serving as the reference educational group in these regressions).

The columns labeled (1) in Table 4 show the residual employment differentials between each group of foreign born men and U.S.-born men (the reference group), after conditioning on the control variables. The control variables produce only minor changes in the estimated immigrant-native employment differentials, so the column (1) coefficients confirm the patterns observed in the raw employment rates in Table 3. Among high school dropouts, the regressionadjusted employment advantage of foreign-born relative to U.S.-born men is 19 percentage points for adult immigrants, 13 percentage points for child immigrants, and 8 percentage points for those born abroad of an American parent. These differentials are just slightly smaller than the raw differentials from Table 3. Among those with at least 12 years of schooling, however, the column (1) coefficients indicate virtually no difference in the adjusted employment rates of U.S.-born men and any group of foreign-born men.

\footnotetext{
${ }^{5}$ Although the dependent variable in these regressions is a dichotomous indicator of employment status, we choose to report least squares estimates (i.e., linear probability models) because the coefficients are easier to interpret. Probit estimates, however, imply similar marginal effects. In order to account for the heteroskedasticity that arises with linear probability models (or for other reasons), we report robust standard errors (White 1980) in parentheses for all regressions.

${ }^{6}$ The controls for age are dummy variables identifying five-year age intervals (i.e., 30-34, 35-39, ..., 55-59, with 25-29 serving as the omitted reference group). The controls for geographic location are dummy variables identifying the nine Census divisions (with the Pacific region serving as the omitted reference group) and whether the respondent lives outside of a
} 
The columns labeled (2) in Table 4 distinguish adult immigrants by how long they have lived in the United States. The estimates reveal a sharp jump in the employment rate of adult immigrants after their first couple of years in the United States, and thereafter employment seems to change little with further time in the country. ${ }^{7}$ This initial jump in employment, gleaned by comparing adult immigrants in their first two years after arrival with those who have been in the United States for three to five years, is smaller for high school dropouts (3.5 percentage points) than for immigrants with at least 12 years of schooling (7.5 percentage points). Nonetheless, if we disregard the very recent arrivals and instead focus on the employment rates of adult immigrants who have been here long enough to be past the initial period of adjustment to the U.S. labor market, then we see the same pattern of results as before. In the lowest education group—-those with less than 12 years of schooling —adult immigrants hold an employment advantage of almost 20 percentage points over U.S.-born men. Among men with higher levels of schooling, employment rates do not differ much by nativity, once we focus on adult immigrants who have had some time to adjust to their new surroundings.

Hispanics and blacks represent disproportionate shares of U.S.-born men with less than 12 years of schooling. For a variety of reasons, employment rates are particularly low for black men (Welch 1990, Juhn 1992), which raises the concern that the employment comparison between low-skill immigrants and natives is distorted by the unique circumstances of blacks and other disadvantaged minority groups in the native population. To explore this issue, Table 5

metropolitan area. The controls for ACS survey year are dummy variables identifying 2006 and 2007 (with 2005 serving as the omitted reference year).

${ }^{7}$ Because they come from a very narrow time period (2005-2007), the data analyzed here are incapable of distinguishing assimilation and cohort effects (Borjas 1985, 1995a), but other studies that follow immigrant arrival cohorts across Censuses show that the depressed labor force activity of recent arrivals primarily represents an adjustment process that all immigrant cohorts experience during their first few years in the United States. See, for example, Chiswick, Cohen, and Zach (1997), Funkhouser and Trejo (1998), Schoeni (1998), Funkhouser (2000), and Antecol, Kuhn and Trejo (2006). 
reports coefficients from regressions identical to the column (1) specification in Table 4, except that we now distinguish by race/ethnicity within each nativity group. The reference group for the resulting comparisons is U.S.-born, non-Hispanic whites, and the reported coefficients represent employment differentials (conditional on the control variables) between men of each nativity/ethnicity group and this reference group. To focus on the most important groups, Table 5 reports only the coefficients for U.S.-born men and for adult immigrants.

In terms of immigrant-native comparisons, the same qualitative patterns emerge as before. Even when compared to U.S.-born, non-Hispanic whites, adult immigrants from every racial/ethnic group display large employment advantages when the sample is restricted to men in the lowest education category. These employment differentials range from 11-13 percent for Asian, white, and black immigrants to 16-17 percent for "other race" and Hispanic immigrants. Also as before, the corresponding differentials remain small among men with at least 12 years of schooling, ranging from an employment disadvantage of 3 percent for Asian immigrants to an employment advantage of 2 percent for Hispanic immigrants. In addition, Table 5 highlights significant racial/ethnic disparities in employment among U.S.-born men. Looking at native high school dropouts, for example, the employment rate is 15 percentage points lower for African-American than for white men. The analogous comparison for non-dropouts produces a smaller but still sizeable employment deficit of 8 percentage points for African-American men. U.S.-born men in the "other race” category also exhibit relatively low employment rates.

On the whole, this analysis suggests that finding paid employment is not a major problem for U.S. immigrants. After a period of adjustment during the first few years upon arrival, the overall employment rate of immigrant men quickly approaches and ultimately slightly exceeds that of U.S.-born men. Among those with the lowest education levels, immigrants exhibit 
substantially higher rates of employment than comparable natives, and this is true for immigrants from every major racial/ethnic group, even in comparison to U.S.-born, non-Hispanic whites. ${ }^{8}$ Despite ongoing structural changes in the U.S. labor market—including the widening of the earnings distribution and the steep rise in the reward associated with additional years of formal schooling —employer demand for low-skill immigrant workers has remained high. Reinforcing this conclusion are the high employment propensities of Hispanic immigrants (see Table 5), a group with very low levels of schooling (see Tables 1 and 2).

\section{B. Wages}

Perhaps the ultimate indicator of labor market success is wages (i.e., average hourly earnings), since wages reflect the market's valuation of a worker's entire package of abilities and attributes, including those for which data are often lacking (e.g., family background, or the quality of schooling). For this reason, it is informative to compare the wages of foreign-born and U.S.-born workers, both with and without controls for observable human capital. Before doing so, however, we need to introduce English language proficiency as an important dimension of human capital that is closely related to nativity and wages.

The ACS data provide self-reported information on English ability, and we display some of this information in Table 6. All respondents were asked whether they "speak a language other than English at home," and only those who answered affirmatively were asked how well they speak English, with possible responses of "very well," "well," "not well,” or "not at all.” The top panel of Table 6 shows, separately for each nativity group, the percentage distribution of

\footnotetext{
${ }^{8}$ In other work (Duncan and Trejo 2009b), we explore in greater detail the immigrant employment advantage among low-skill men, and we argue that this finding is consistent with the migrant selectivity that arises naturally in a model where potential migrants jointly choose location and labor force participation.
} 
men across the following three-way categorization of English proficiency: those who speak no other language besides English, those who speak another language and report speaking English "very well” or "well," and those who speak another language and report speaking English "not well” or "not at all." Perhaps not surprisingly, over a third of adult immigrants fall into the lowest category of English ability, whereas only 11 percent of child immigrants and 3 percent of those born abroad of an American parent report this same level of deficiency in English. Within each nativity group, the bottom panel of Table 6 further distinguishes high school dropouts from those with at least 12 years of schooling. There is a strong relationship between education and English ability among foreign-born men, with the proportion of dropouts reporting the lowest category of English proficiency reaching 65 percent for adult immigrants, 36 percent for child immigrants, and 20 percent for those born abroad of an American parent.

Table 7 presents wage regressions in which the dependent variable is the natural logarithm of average hourly earnings during the twelve months preceding the survey date. The sample is now limited to employed men, and observations with average hourly earnings below $\$ 1$ or above $\$ 1,000$ are excluded as outliers. The regression specifications are identical to those used for the employment regressions in Table 4, except that the columns labeled (3) add controls for English proficiency. The column (1) estimates reveal that, on average, adult immigrants earn about 20 percent less than U.S.-born men, and that this wage gap is similar among high school dropouts as among those with at least 12 years of schooling. The corresponding wage deficit is much smaller for immigrants who arrived as children: 7 percent among high school dropouts and 3 percent among those with at least 12 years of schooling.

In the column (2) specification, adult immigrants are distinguished by how long they have been in the United States. During their first two years after arrival, adult immigrants 
display a wage gap relative to U.S.-born men of over 30 percent, but this gap narrows for immigrants with longer durations of U.S. residence. For adult immigrants who have lived in the United States for more than 20 years, the wage deficit falls to 8 percent among high school dropouts and 13 percent among those with at least 12 years of schooling. Following Chiswick (1978), economists have analyzed how immigrant wages vary with duration of U.S. residence in order to gauge labor market assimilation. In his influential study, Chiswick analyzed data from the 1970 Census and concluded that the earnings of immigrants grow rapidly as they adjust to the U.S. labor market and acquire U.S.-specific human capital (including proficiency in the English language). Chiswick's analysis suggests that the immigrants in his data erased their initial earnings deficit relative to natives within ten or fifteen years after arrival and went on to outearn natives in the later stages of their careers.

As noted by Borjas $(1985,1995 a)$, however, cross-sectional analyses of earnings (such as Chiswick's study or the column (2) regressions reported in Table 7) can give a misleading view of immigrant assimilation, because such analyses confound the effects of duration of U.S. residence and arrival cohort (i.e., at any given point in time, variation across immigrants in years of U.S. residence arises only from differences in year of entry to the United States). In particular, over the last half of the twentieth century, dramatic changes occurred in the national origin and skill composition of U.S. immigrant flows. The share of immigrants originating in Europe and Canada fell sharply, with the slack taken up by surging immigration from Asia and Latin America. A substantial body of research shows that more recent immigrant arrival cohorts are less skilled and have been less successful in the labor market than earlier cohorts, and that there are important links between the shifts in national origins and declining immigrant skills 
(Borjas 1992, 1994a, 1999; Card 2005). ${ }^{9}$ Contrary to the traditional view that immigrants rapidly assimilate into the economic mainstream of American society, the revisionist studies predict that most foreign-born workers who entered the United States in recent years will throughout their lifetimes earn substantially less than native workers (Borjas 1995a).

To date, Lubotsky (2007) provides the most convincing estimates of post-migration earnings growth for foreign-born workers in the United States. By employing longitudinal data from the social security earnings histories of individual workers, Lubotsky’s analysis not only addresses unobserved heterogeneity across immigrant arrival cohorts, but it also accounts for selective emigration. Though correcting for these factors lowers estimates of immigrant earnings growth, Lubotsky still finds evidence of substantial earnings assimilation for foreign-born workers in the United States: "over their first 20 years in the United States, immigrant earnings grow by 10-15 percent relative to the earnings of native-born workers” (Lubotsky 2007, p. 864). Consistent with other research (Borjas 1995a; Trejo 2003; Blau and Kahn 2007; Borjas and Katz 2007), Lubotsky also finds that earnings assimilation is considerably slower for Hispanic (predominately Mexican) immigrants than for other immigrants.

The wage regressions reported in the columns labeled (3) in Table 7 add dummy variables indicating self-reported English proficiency, with the reference group consisting of those who speak no other language besides English. Consistent with other studies (McManus, Gould, and Welch 1983; Chiswick and Miller 1995; Bleakley and Chin 2004), these estimates imply large economic returns to English proficiency. ${ }^{10}$ For example, among high school

\footnotetext{
${ }^{9}$ In particular, immigrant earnings in the United States are strongly correlated with per capita Gross National Product in the source country (Jasso and Rosenzweig 1986; Borjas 1987), presumably because workers from industrialized countries are better trained than workers from developing countries and their skills transfer more readily to the U.S. labor market.

${ }^{10}$ Under a human capital interpretation, the coefficients on the English proficiency dummies measure the increase in productivity that accompanies learning to communicate in the dominant language, but other factors may contribute to the observed correlation between wages and ability to speak English. For example, the English proficiency coefficients may capture
} 
dropouts who speak a language other than English, those who speak English "very well” earn 16 percent more than those who speak English "not well” and 27 percent more than those who speak English “not at all.” The corresponding payoffs to English ability are even higher among those with at least 12 years of schooling. Moreover, the dramatic reduction in the residual wage deficits of foreign-born workers as we move from column (2) to column (3) indicates that the lower English skills of immigrants account for most of their earnings disadvantage relative to comparable U.S.-born workers. The estimates in column (3) suggest that wage differences are small between foreign-born and U.S.-born workers who possess similar levels of human capital (i.e., education and English proficiency). For example, wage deficits (relative to natives) are no more than five percent for adult immigrants who have had at least six years to adjust to life in the United States, and immigrants who arrived as children actually enjoy a slight wage advantage. Overall, the earnings of U.S. immigrants seem to be commensurate with the skills they bring to the labor market.

Table 8 presents selected coefficients from wage regressions that distinguish by race/ethnicity within each nativity group. Otherwise, the column (1) specification in Table 8 is identical to the column (1) specification in Table 7. The column (2) specification in Table 8 adds controls for English proficiency. The reported coefficients represent regression-adjusted wage differentials between men of each nativity/ethnicity group and U.S.-born, non-Hispanic 
whites (the reference group). Among U.S.-born workers, black men earn on average about 20 percent less than white men with the same level of education, whereas the corresponding wage gaps are substantially smaller for native men from other racial/ethnic groups, with this gap essentially disappearing for U.S.-born Asians. For adult immigrants from all racial/ethnic groups, English language deficiencies account for sizeable portions of their wage deficits relative to U.S.-born whites. Indeed, after conditioning on English proficiency, immigrant high school dropouts from all groups except Asians earn as much or more as native dropouts from the same racial/ethnic group (e.g., among dropouts, the column (2) specification shows Hispanic immigrants earning 12 percent less than U.S.-born whites, whereas the analogous wage deficit is slightly larger for U.S.-born Hispanics). Among those with at least 12 years of schooling, however, wages are significantly higher for U.S.-born compared to foreign-born Hispanics and blacks (as well as Asians), even after controlling for English proficiency. Nevertheless, once we condition on observable skills, the largest remaining wage deficits in Table 8 tend to be associated with race (black and, to a lesser extent, “other race”) rather than with nativity.

\section{Illegal Immigration}

A key feature of U.S. immigration is that much of it is undocumented. The clandestine nature of illegal immigration makes this population difficult to observe, but some credible information is available nonetheless. Passel (2007) estimates that undocumented immigrants represent almost a third of the total foreign-born population living in the United States as of March 2006, and the undocumented share is much higher among recent arrivals who have been in the country for ten years or less. Passel also shows that undocumented immigrants are

by the more severe downward bias generated by measurement error in the data describing English language skills. Therefore, 
overwhelmingly Hispanic, with 57 percent originating in Mexico and another 26 percent coming from elsewhere in Latin America. Indeed, Passel (2004) reports that over 80 percent of all Mexican immigrants who arrived in the United States after 1990 were undocumented as of March 2002.

How does legal status, by itself, affect the labor market opportunities of immigrants? Most data sources cannot identify illegal immigrants, and so they are unable to answer this question. A few studies, however, have been able to shed light on the issue by exploiting unique surveys that contain information about legal status. Chiswick (1988), for example, analyzes samples of illegal immigrants who had been apprehended by the Immigration and Naturalization Service (as it was called back then), and he shows that their U.S. earnings are systematically related, in expected ways, to variables that proxy for labor market skills (i.e., education, work experience, seniority with the current employer, and duration of U.S. residence). Massey (1987) compares the U.S. wages earned by legal and illegal immigrants originating in four Mexican communities. He reports that undocumented Mexican immigrants earn substantially less, on average, than do legal Mexican immigrants, but he also shows that this wage gap is explained by the lower human capital possessed by undocumented immigrants, particularly with regard to English proficiency and U.S. work experience. After controlling for observable determinants of earnings, Massey finds that legal status per se has little direct effect on U.S. wages for the Mexican immigrants in his sample. Donato and Massey (1993), however, obtain a different result when they conduct a similar analysis of later and more extensive data from 13 Mexican communities. In these later data, undocumented status reduces wages by about 20 percent, even after controlling for observables. 
Perhaps the best evidence on the labor market impact of legal status comes from a survey that tracked the experiences of initially-undocumented immigrants before and after they were granted permanent legal resident status through the amnesty provisions of the 1986 Immigration Reform and Control Act (IRCA). Despite using somewhat different approaches to analyzing these data, Rivera-Batiz (1999) and Kossoudji and Cobb-Clark (2002) reach similar conclusions. First, holding observable skills constant, estimates suggest that legalization raised the wages of these workers by about 5-10 percent relative to what their wages would have been had the workers remained undocumented. Second, by increasing the incentives for these workers to invest in human capital, legalization also may have induced greater skill acquisition and thereby boosted wages through this indirect channel.

Although data limitations preclude strong conclusions on this topic, available research suggests that labor market skills play a much bigger role than legal status in determining economic outcomes for U.S. immigrants. For example, the low wages earned by recent immigrants from Mexico and Central America, many of whom are undocumented, are primarily due to their low levels of education and English proficiency, not their illegal status (Duncan, Hotz, and Trejo 2006). Unskilled immigrants, whether legal or illegal, tend to be treated similarly by the U.S. labor market.

\section{The Second and Third Generations}

Historically, much of the socioeconomic mobility achieved by U.S. immigrant families has taken place across rather than within generations. For example, previous waves of predominantly unskilled immigrants, such as the Italians and Irish, enjoyed substantial intergenerational progress that ultimately enabled their descendants to join the economic 
mainstream of American society, but this process took at least two or three generations to unfold (Chiswick 1977; Neidert and Farley 1985; Lieberson and Waters 1988; Farley 1990; Borjas 1994b; Perlmann and Waldinger 1997; Alba and Nee 2003; Perlmann 2005). There is considerable skepticism, however, that the processes of assimilation and adaptation will operate similarly for the predominantly non-white immigrants who have entered the United States in increasing numbers over the past several decades (Gans 1992; Portes and Zhou 1993; Rumbaut 1994). Indeed, Huntington (2004) voices a particularly strong version of such skepticism with regard to Hispanic immigration. When assessing the long-term economic integration and impact of immigrants, it is therefore important to analyze differences not just between the foreign-born and U.S-born, but also, when possible, across generations of the U.S.-born (Borjas 1993; Card 2005; Smith 2006). In this section, we explore what available data can tell us about such intergenerational patterns.

\section{A. Outcomes by Immigrant Generation}

Beginning in 1980, the decennial Census stopped asking respondents about the countries of birth of their parents, and the ACS follows the Census in this regard. Starting in 1994, however, the Current Population Survey (CPS) began collecting this information on a regular basis from all respondents. As a result, the CPS is currently the best large-scale U.S. data set for investigating how outcomes vary by immigrant generation. For the analyses in this section, we employ CPS microdata for all months from January 2003 through December 2009. ${ }^{11}$ The time

\footnotetext{
${ }^{11}$ The CPS is a monthly survey of about 60,000 households that the U.S. government administers to estimate unemployment rates and other indicators of labor market activity. In addition to the detailed demographic and labor force data reported for all respondents, the CPS collects earnings information each month from one-quarter of the sample, the so-called “outgoing rotation groups." The data we analyze come from these outgoing rotation group samples. The CPS sampling scheme is such that surveys for the same month in adjacent years have about half of their respondents in common (e.g., about half of the respondents in any January survey are re-interviewed the following January). To obtain independent samples, we use only data
} 
frame of our CPS sample is therefore centered on the years of ACS data (2005-2007) analyzed earlier. As we did with the ACS data, we restrict our CPS sample to men ages 25-59 who do not reside in institutions.

Using the CPS information on the countries of birth of each individual and his parents, we define the following nativity/generation groups. Foreign-born individuals are assigned to the same three categories employed with the ACS data: those born abroad of an American parent, "child immigrants" who arrived in the United States before the age of 16, and "adult immigrants" who arrived at age 16 or later. ${ }^{12}$ U.S.-born individuals, however, are now distinguished by the nativity of their parents. Standard practice is for the "second generation" to include all U.S.-born individuals who have at least one foreign-born parent, but members of this group with one U.S.-born and one foreign-born parent have unique experiences and often display different socioeconomic outcomes than their peers with two foreign-born parents (Portes and Rumbaut 2001; Ramakrishnan 2004; Rumbaut 2004). Therefore, we assign U.S.-born individuals to three groups: those with two foreign-born parents (sometimes referred to as the “2.0 generation"), those with parents of "mixed nativity" (i.e., one parent is foreign-born and the other is U.S.-born; this group is sometimes labeled the " 2.5 generation"), and those with two U.S.-born parents (sometimes called the "third and higher generation" or "native born of native parentage”). Compared to the ACS data analyzed earlier, the main advantage of the CPS is this ability to distinguish between the second and higher generations of U.S.-born men. One drawback of the CPS, however, is the absence of information about English proficiency.

\footnotetext{
from the first time a household appears in the outgoing rotation group samples (i.e., we use only data from the fourth month that a household appears in the CPS sample). By pooling together these seven years of monthly CPS data, we substantially increase sample sizes and improve the precision of our estimates.

${ }^{12}$ In the context of immigrant generations, child immigrants are sometimes referred to as the "1.5 generation" (Rumbaut 2004).
} 
Table 9 reports the distribution of our CPS sample by nativity/generation and race/ethnicity and shows sample sizes and average completed years of schooling for the relevant groups. Foreign-born individuals make up just under 20 percent of the sample, and another six percent are second-generation (i.e., U.S.-born individuals with a foreign-born parent), with half of the second generation having two foreign-born parents and the other half with parents of mixed nativity. As we saw with the ACS data, average educational attainment is relatively low for immigrants—-whether they arrived as adults (11.9 years) or as children (12.4 years)— compared to U.S.-born individuals. By the second generation, however, this schooling gap is erased, as both types of second-generation men exhibit education levels at least as high as the average schooling (13.6 years) of third- and higher-generation men.

Among second-generation men, Hispanics stand out as the only racial/ethnic group with educational attainment significantly below that of third-generation whites. Schooling levels are also relatively low for third-generation Hispanics and blacks. As a result, Hispanics assume a central role in current discussions of immigrant intergenerational progress and the outlook for the so-called "new second generation," not just because Hispanics make up a large share of the U.S. immigrant population, but also because most indications of relative socioeconomic disadvantage among the children of U.S. immigrants vanish when Hispanics are excluded from the sample (Perlmann and Waldinger 1996, 1997). Therefore, to a great extent, concern about the long-term economic trajectory of immigrant families in the United States is concern about Hispanic-American families. ${ }^{13}$

In order to investigate how labor market outcomes vary with immigrant generation, Table 10 presents employment and wage regressions from the CPS data. Here, the dependent variable

\footnotetext{
${ }^{13}$ See Smith (2006), however, for a more optimistic take on the intergenerational schooling gains made by Hispanics.
} 
for the employment regressions is a dummy identifying individuals who were employed during the CPS survey week. The dependent variable for the wage regressions is the natural logarithm of average hourly earnings. Unlike the ACS data analyzed earlier, however, the CPS outgoing rotation group data report only earnings from wage and salary jobs (i.e., self-employment income is excluded). Since the focus now is on comparing second-generation men with highergeneration men, and these groups have similar levels of education, we no longer run separate regressions for high school dropouts versus others. Otherwise, these regressions are similar to those reported previously for the ACS data, with controls for age and geographic location, as well as for the survey month and year of each CPS observation.

Overall, Table 10 reveals only minor differences in the labor market outcomes of U.S.born men according to the nativity of their parents. In the column (1) regressions, which do not control for education, U.S.-born men with two foreign-born parents (i.e., 2.0 generation men) exhibit slight deficits in employment (0.9 percentage points) and wages (1.2 percent) relative to third- and higher-generation men, whereas the analogous comparisons actually show small advantages (1.4 percentage points for employment and 3.7 percent for wages) for U.S.-born men with mixed nativity parents (i.e., the 2.5 generation). After controlling for education, these differences become even smaller (see the column (2) regressions), especially the labor market advantages for 2.5-generation men.

Table 11 shows how these labor market differences by nativity/generation vary across racial/ethnic groups. The reported differentials are all relative to the reference group consisting of non-Hispanic white men who are U.S.-born with U.S.-born parents. Among U.S.-born men, blacks stand out with employment and wage deficits that remain large even after conditioning on education. Compared to third- and higher-generation whites with similar education, for 
example, the column (2) estimates imply that the employment rates of U.S.-born blacks are about 12 percent lower for men with zero or one foreign-born parents and 19 percent lower for men with two foreign-born parents. The corresponding wage gaps are around 20 percent for all three groups of U.S.-born black men. Second- and third-generation Hispanic men also exhibit modest employment and substantial wage deficits relative to third-generation whites, but these deficits shrink by half or more after controlling for education. Conditional on observables, the remaining gaps are much smaller for U.S.-born Hispanics (1-2 percentage points for employment and about 9 percent for wages) than they are for U.S.-born blacks, which suggests that labor market opportunities may be more similar to those of whites for Hispanics than for blacks (Trejo 1997; Grogger and Trejo 2002; Duncan, Hotz, and Trejo 2006).

In contrast with blacks and Hispanics, labor market deficits are either small or nonexistent for first- and second-generation white and Asian men. Second-generation Asian men do have somewhat lower employment rates than third-generation whites, however, and wage comparisons for all generations of Asian men become less favorable after controlling for education. As others have noted (Sakamoto, Goyette, and Kim 2009), the schooling advantage of Asian Americans can obscure the fact that they tend to earn somewhat less than Anglos with the same level of education.

\section{B. Intermarriage and Selective Ethnic Attrition}

In this chapter, we have followed the common practice of using self-reported race/ethnicity to approximate the national origins of first- and second-generation immigrants (e.g., a second-generation Hispanic is someone born in the United States who identifies as Hispanic and has a foreign-born parent). An alternative (and perhaps more precise) approach is 
to assign national origins based on the birthplaces of the individual and his parents (e.g., a second-generation Hispanic is someone born in the United States to a parent born in a Spanishspeaking country). For foreign-born individuals, the two approaches to assigning national origins yield very similar samples and results (Rumbaut 2004; Perez and Hirschman 2009). For second-generation individuals, a modest amount of ethnic attrition becomes discernable (e.g., U.S.-born individuals who do not self-identify as Hispanic despite being the children of immigrants from a Spanish-speaking country), but the overall impact on measured characteristics of the population remains small (Rumbaut 2004; Duncan and Trejo 2011a). It is in the third and later generations where intermarriage and assimilation complicate ethnic identification to an extent that might distort our inferences about the socioeconomic attainment of the descendents of immigrants. Although this issue is difficult to study with available data, it is increasingly recognized as an important consideration when assessing the long-term integration of some immigrant groups (Bean et al. 2005; Alba and Islam 2009; Duncan and Trejo 2011b, 2011c).

Frequent intermarriage is one of the strongest signals of social assimilation by an ethnic group with immigrant origins (Gordon 1964; Alba and Nee 2003). In addition, intermarriage is a key determinant of weakened and/or multiple ethnic attachments for future generations of the group (Hout and Goldstein 1994, Perlmann and Waters 2007). After a few generations in the United States, so much intermarriage had taken place among the descendants of earlier European immigrants that most white Americans could choose among multiple ancestries or ethnic identities (Alba 1990; Waters 1990). For such individuals, ethnicity has become subjective, situational, and largely symbolic, and the social boundaries between these ethnic groups have been almost completely erased.

Recently, we have begun to study to linkages between intermarriage, generational 
complexity, and ethnic identification for the specific case of Mexican Americans (Duncan and Trejo 2007, 2009a, 2011a, 2011c). We find that selective ethnic attrition creates potentially serious problems for tracking the socioeconomic progress of the U.S.-born descendants of Mexican immigrants. Almost without exception, studies of later-generation Mexican Americans rely on subjective measures of ethnic self-identification to identify the population of interest. As the descendants of Mexican immigrants assimilate into American society and often intermarry with non-Mexicans, ethnic identification weakens, particularly among the children produced by Mexican intermarriages. Unfolding across generations, this dynamic suggests that an increasingly small fraction of the descendants of Mexican immigrants continue to identify themselves as Mexican. Moreover, this process of ethnic leakage is highly selective, because Mexican Americans who intermarry tend to have much higher education and earnings than Mexican Americans who do not intermarry. Consequently, available data for third- and highergeneration Mexicans, who usually can only be identified by their subjective responses to questions about Hispanic ethnicity, understate the socioeconomic attainment of this population.

We uncover several different kinds of empirical evidence that are consistent with this story. Data from the 1970 Census Content Reinterview Study suggest that self-identified samples of U.S. Hispanics omit a large proportion of later-generation individuals with Hispanic ancestors, and that intermarriage is a fundamental source of such intergenerational ethnic attrition (U.S. Bureau of the Census 1974, page 8, Table C). Data from the 2000 Census indicate that intermarriage is widespread among Mexican Americans. More than a third of married, U.S.born Mexicans have non-Mexican spouses, with the overwhelming majority of these nonMexican spouses being U.S.-born, non-Hispanic whites. Because it takes two Mexican-origin spouses to create an endogamous Mexican marriage, whereas a Mexican intermarriage requires 
only one Mexican-origin spouse, the observed rate of intermarriage implies that almost half of Mexican-American marriages involve a non-Mexican spouse. In addition, Mexican intermarriage is highly selective on human capital and labor market success, and having a nonMexican parent largely determines whether children of Mexican descent are at risk of losing their Mexican identity (Duncan and Trejo 2007). Taken together, these findings provide a mechanism for selective ethnic attrition among Mexican Americans. Those Mexicans who intermarry tend to have higher levels of education and earnings, and many of the resulting children are not identified as Mexican in Census data. In this way, selective intermarriage interacts with the intergenerational transmission of human capital and ethnic identity to create a situation in which available data for later-generation Mexican Americans may omit an increasingly large share of the most successful descendants of Mexican immigrants.

Two pieces of indirect evidence corroborate the direction of the measurement bias generated by this process of selective ethnic attrition. First, in 1980 Census data for five southwestern states where the Hispanic population was overwhelmingly Mexican origin at that time, men with a Spanish surname who nonetheless self-identify as "not Hispanic” are much more educated and English proficient, on average, than their counterparts who are consistently identified as Hispanic by both surname and self-report (Duncan and Trejo 2007). Second, in 2000 Census data, human capital advantages are also evident for men who list a Mexican ancestry but simultaneously report their ethnicity as "not Hispanic," relative to men who report Mexican as both their ancestry and their ethnicity (Duncan and Trejo 2009a). In each case, the segment of the Mexican-American population that seems to have weaker or more distant ethnic ties displays significantly higher levels of socioeconomic attainment.

Finally, using data on U.S.-born Mexican-American children from recent years of the 
CPS, we provide some direct evidence of selective ethnic attrition (Duncan and Trejo 2011a). For children living with both parents, the CPS data reveal how many parents and grandparents were born in Mexico. We assess the influence of endogenous ethnicity by comparing an "objective” indicator of Mexican descent (based on the countries of birth of the child, his parents, and his grandparents) with the standard "subjective” measure of Mexican selfidentification (based on the response to the Hispanic origin question). Immigrant generations turn out to be quite complex, and this complexity is closely related to children's subjective Mexican identification. For example, only 17 percent of third-generation Mexicans have a majority of their grandparents born in Mexico. Moreover, third-generation children are virtually certain of identifying as Mexican if three or more grandparents were born in Mexico, whereas rates of Mexican identification fall to 79 percent for children with two grandparents born in Mexico and 58 percent for children with just one Mexican-born grandparent. Overall, about 30 percent of third-generation Mexican children fail to self-identify as Mexican in our CPS sample, and this ethnic attrition is highly selective. For example, the high school dropout rate of thirdgeneration Mexican youth is 25 percent higher when the sample is limited to those youth who self-identify as Mexican. Therefore, these CPS data provide some direct evidence that ethnic attrition is substantial and could produce significant downward bias in standard measures of attainment which rely on ethnic self-identification rather than objective indicators of Mexican descent.

For other groups, previous research illustrates how selective ethnic identification can distort observed socioeconomic characteristics. American Indians are a particularly apt example, because they exhibit very high rates of intermarriage, and fewer than half of the children of such intermarriages are identified as American Indian by the Census race question (Eschbach 1995). 
For these and other reasons, racial identification is relatively fluid for American Indians, and changes in self-identification account for much of the surprisingly large increase in educational attainment observed for American Indians between the 1970 and 1980 U.S. Censuses (Eschbach, Supple, and Snipp 1998). In addition, Snipp (1989) shows that those who report American Indian as their race have considerably lower schooling and earnings, on average, than the much larger group of Americans who report a non-Indian race but claim to have some Indian ancestry. To cite another example, Waters $(1994,1999)$ observes selective ethnic identification among the U.S.-born children of New York City immigrants from the West Indies and Haiti. The teenagers doing well in school tend to come from relatively advantaged, middle-class families, and these kids identify most closely with the ethnic origins of their parents. In contrast, the teenagers doing poorly in school are more likely to identify with African Americans. This pattern suggests that self-identified samples of second-generation Caribbean blacks might overstate the socioeconomic achievement of this population, a finding that potentially calls into question the practice of comparing outcomes for African Americans and Caribbean blacks as a means of distinguishing racial discrimination from other explanations for the disadvantaged status of African Americans (Sowell 1978).

As noted earlier, existing empirical research raises concerns that some Hispanic groups, including Mexicans, are experiencing markedly less intergenerational progress than other immigrant groups (Perlmann and Waldinger, 1996, 1997; Portes and Rumbaut 2001; Huntington 2004; Perlmann 2005). Do our results mitigate such concerns? We show that available data are likely to understate the socioeconomic achievement of later-generation Mexican Americans, but what does this imply about their standing relative to other immigrant groups? Given that intermarriage is the primary source of this bias, we might expect similar or larger biases for other 
immigrant groups, because most other groups exhibit intermarriage rates at least as high as those of Mexicans (Lieberson and Waters 1988; Lichter and Qian 2005). If the direction of the bias is the same for all groups, then appropriate corrections could produce no improvement or even deterioration in the relative position of Mexican Americans.

We have begun to investigate selective ethnic attrition for national origin groups besides Mexicans, and our preliminary findings suggest that correcting for the resulting biases will in fact raise the attainment of later-generation Hispanic Americans relative to the descendants of most other U.S. immigrant groups (Duncan and Trejo 2011b). Like Mexicans, Puerto Ricans are an Hispanic group that shows signs of intergenerational stagnation, and the extent and selectivity of ethnic attrition seems roughly similar for U.S.-born Puerto Ricans as for Mexican Americans. The selectivity of ethnic attrition is reversed, however, for Asian-American groups with comparatively high levels of education, such as U.S.-born Chinese, Japanese, Koreans, and Indians. Among the descendants of immigrants from these Asian countries, those with fewer years of schooling are less likely to retain an Asian identification, which suggests that ethnic attrition inflates standard measures of socioeconomic attainment for later-generation Asian Americans. Furtado (2006) advances a model of interethnic marriage that potentially explains why the selectivity of ethnic attrition works in the opposite direction for low-education Hispanic groups versus high-education Asian groups. ${ }^{14}$ Therefore, Furtado’s theoretical insights and our own preliminary empirical work both provide reasons to suspect that ethnic attrition generates

\footnotetext{
${ }^{14}$ Furtado's model emphasizes how the supplies of potential spouses vary with ethnic-specific schooling distributions in marriage markets where individuals hope to match on both education and ethnicity. A college-educated Mexican American, for example, may choose to intermarry because of the relative scarcity of other Mexican ethnics with a college degree. Asian Americans tend to be overrepresented on college campuses, however, so for these groups it may instead be the less-educated individuals that face a more difficult time finding co-ethnics to marry within their education group. Consequently, this model predicts that members of high-education groups who intermarry should be negatively selected in terms of education, whereas the selectivity should be positive for intermarried members of low-education groups. Because intermarriage is a fundamental source of ethnic attrition, the differences across groups in intermarriage selectivity predicted by Furtado's model can generate corresponding differences in the selectivity of ethnic attrition.
} 
measurement biases that vary across national origin groups in direction as well as magnitude, and that correcting for these biases will raise the relative socioeconomic standing of the U.S.born descendants of Hispanic immigrants.

\section{Impact on Native Workers}

In recent years, many studies have attempted to estimate the impact of immigration on the wages and employment opportunities of U.S.-born workers. Useful surveys of the academic literature on this topic include Borjas (1994a, 1999), Friedberg and Hunt (1995), Smith and Edmonston (1997, Chapters 4-5), Card (2005, 2009), and Raphael and Ronconi (2007). Lowenstein (2006) provides a non-technical discussion of the key issues that is both readable and nuanced.

For the most part, the empirical methodology used to estimate the impact of immigration on native workers has been to compare labor market outcomes (e.g., wages, employment rates, or unemployment rates) for natives in U.S. metropolitan areas that did and did not receive large inflows of immigrants. For example, over the past few decades, cities such as Los Angeles and Houston have received many new immigrants, especially unskilled immigrants, whereas other cities like Cleveland and Pittsburgh received few immigrants. Over this period, how have earnings and employment opportunities changed for native workers who might be thought to compete for jobs with unskilled immigrants, such as native workers who did not finish high school? If labor market competition with immigrants harmed unskilled native workers, then we would expect the wages and employment rates of unskilled natives in high-immigration cities like Los Angeles and Houston to have deteriorated relative to their counterparts in lowimmigration cities such as Cleveland and Pittsburgh. 
This type of analysis suggests that, on average, immigration has only very modest effects on the labor market opportunities of native workers, even of unskilled natives. Statistical correlations are weak across U.S. metropolitan areas between measures of immigrant penetration and native labor market outcomes. This remains true even after controlling for observable differences across cities (in, for example, demographics or industrial composition), and even when comparing intertemporal changes in immigrant inflows and native outcomes (in order to control for unobservable differences between cities that persist over time). After reviewing the available evidence, a National Academy of Sciences panel assembled to evaluate the impacts of U.S. immigration concluded that the "weight of the empirical evidence suggests that the impact of immigration on the wages of competing native-born workers is small—possibly reducing them by only 1 or 2 percent” (Smith and Edmonston 1997, p. 220). Similarly, Friedberg and Hunt (1995, p. 42) conclude their survey of the academic literature on the topic with the statement: "Despite the popular belief that immigrants have a large adverse impact on the wages and employment opportunities of the native-born population, the literature on this question does not provide much support for this conclusion.”

An important potential problem with the empirical methodology used in much of the literature is that immigrants may be choosing to locate in U.S. metropolitan areas with the most dynamic local economies. If sunbelt cities like Los Angeles and Houston are booming, then even with a large influx of immigrants, wage and employment growth for native workers in these cities may match or exceed the corresponding growth for native workers in less prosperous cities like Cleveland and Pittsburgh. What we really want to know, however, is whether labor market outcomes for natives in Los Angeles and Houston would have been even more favorable in the absence of the immigrant influx. Convincingly answering this kind of counterfactual question is 
typically difficult to do in nonexperimental settings. It would be easier to answer this question if we could study a large, exogenous, and unexpected inflow of immigrants to a particular city.

In an influential paper, Card (1990) studied an immigrant inflow that plausibly satisfies these conditions. In April 1980, Fidel Castro unexpectedly announced that Cubans wishing to emigrate to the United States were free to leave from the port of Mariel. From May to September 1980, some 125,000 Cuban immigrants arrived in Miami on boats and rafts. Half of these so-called Mariel immigrants settled permanently in Miami, increasing the city’s labor force by 7 percent and its Cuban work force by 20 percent. This influx of Mariel immigrants thus produced a large and unexpected increase in the supply of unskilled labor in Miami. Card estimates the impacts of this surge of unskilled immigrants by tracking labor market outcomes for native workers in Miami during the years before and after the Mariel boatlift. In order to control for overall labor market trends, Card also compares the experiences of native workers in Miami with the experiences of native workers in four other metropolitan areas chosen for being similar to Miami demographically and economically: Atlanta, Houston, Los Angeles, and Tampa-St. Petersburg. Card's analysis finds no evidence that the Mariel immigrants adversely affected the wages, employment rates, or unemployment rates of native workers in Miami.

The textbook model of supply and demand predicts that, when a large influx of immigrants shifts out the supply of labor in a market, the equilibrium wage should fall as a consequence of movement along the downward-sloping demand for labor curve. It was therefore surprising to economists that spatial correlations (across U.S. metropolitan areas) between immigrant inflows and native worker outcomes suggest that immigrants do not significantly affect the wages or employment opportunities of natives. What could account for this result? One possibility is that the location decisions of native workers help to mitigate the 
local labor market effects of immigration. In response to any decline in labor market opportunities caused by a large immigration influx into a particular city, natives might leave that city or alter plans they had to move into that city. Indeed, Card (1990, p. 257) finds some evidence that "the net migration rate of natives and earlier immigrants into the Miami area slowed considerably after the Boatlift. To some extent the Mariels may have displaced other migrants from within the United States who could have been expected to move to Miami.” There is disagreement, however, over the ultimate importance of this factor. Looking at data for a large number of cities in the late 1980s, Card (2001, p. 47) concludes that "mobility flows of natives and older immigrants are not very sensitive to inflows of new immigrants.” On the other hand, using a somewhat different methodology applied to data for the 1960-2000 period, Borjas (2006) finds a bigger impact of immigration on native internal migration.

Capital is also potentially mobile, given enough time, so if immigration were to lower the wages of unskilled workers in particular cities, businesses that intensively employ unskilled labor may move to or expand in these cities in order to take advantage of the low wages. Contrary to this explanation, Lewis (2003) and Card and Lewis (2007) show that when metropolitan areas receive an influx of unskilled immigrants, only a small portion of the influx is absorbed through an expansion of industries that intensively employ unskilled workers. Instead, most of the adjustment takes place within industries; in other words, cities that receive large inflows of unskilled immigrants tend to use unskilled labor more intensively—in all industries— than do cities that receive fewer unskilled immigrants. Lewis (2011) provides evidence that, in metropolitan areas where unskilled workers are plentiful due to immigration, industries are less likely to adopt advanced technologies such as automation that can substitute for unskilled labor. Because of the possibility that equilibrating reallocations of labor and capital within the 
United States might make it difficult to detect the effects of immigration by comparing cities or regions, Borjas (2003) argues that it is best to analyze U.S. immigration at the national level. Instead of using the geographic clustering of immigrants to identify their impact, Borjas exploits the fact that new immigrant arrivals are concentrated in particular age groups and education levels, and that the extent and nature of this concentration has changed over time. Workers are sorted into cells defined according to age (as a proxy for work experience) and education, with each cell meant to represent workers with similar labor market "skills.” Because education remains fixed for most workers after they enter the work force full-time as adults, Borjas argues that native workers are unlikely to move across these skill categories in response to immigration. He therefore estimates the effects of immigration by examining how the earnings and employment of natives in a particular skill group respond to immigration-induced changes in the supply of labor in that same skill group. Contrary to most of the previous literature, Borjas's approach produces estimates which imply that immigrants significantly depress the labor market opportunities of competing native workers. Using his estimates to simulate the impact of the large and relatively unskilled influx of immigrants that the United States received between 19802000, Borjas concludes that the adverse effects of immigrants on wages fell most heavily on younger native workers who failed to complete high school—in other words, the least skilled native workers.

As noted by Ottaviano and Peri (2011), however, the ultimate magnitude of immigration's impact on native wages implied by an analysis of this type hinges on two key issues. ${ }^{15}$ The first issue is how quickly the stock of productive capital (e.g., equipment, machinery, plant size, etc.) adjusts to the influx of immigrants. Borjas's simulations focus on the 
"short run" situation in which the capital stock does not adjust at all to immigration. Standard economic theory predicts that in the "long run"-i.e., after the capital stock fully adjusts to an influx of immigrants—-the average wage returns to the same level it was before these immigrants arrived. The wages paid to particular skill groups of workers can rise or fall because of immigration, even in the long run, but the overall average wage is not affected once capital has adjusted. Therefore the time it takes the capital stock to respond to an influx of immigrants is important for determining immigration's aggregate impact, because immigration can have a nonzero net effect on the overall wage only during the transition period when capital is adjusting. The second issue is whether, in their roles as inputs in the production process, immigrant and native workers in the same age/education group are perfect substitutes for each other. To the extent that immigrant and native workers, even those with otherwise similar observable characteristics, have somewhat different skills and are therefore imperfect substitutes as inputs, then any adverse labor market impacts of immigration might fall mainly on the immigrants themselves (both new and previous arrivals) rather than on natives.

Ottaviano and Peri (2011) provide evidence that immigrant and native workers are indeed imperfect substitutes within age/education groups. Incorporating both imperfect substitution and the gradual adjustment of capital into their simulations, Ottaviano and Peri (2011) produce estimates of immigration's impact on native workers that are much more favorable than those produced by Borjas (2003). According to Ottaviano and Peri, the only group of native workers harmed by immigration is U.S.-born high school dropouts, and the wage losses suffered by this group are small. Instead, immigration generates large wage reductions for foreign-born workers of all education levels.

\footnotetext{
${ }^{15}$ Peri (2006a, 2006b, 2007) provides non-technical discussions of these particular issues and the general topic of
} 
Because no consensus has been reached, it is not straightforward to summarize the findings of academic research on the impact of immigration on native workers. One important conclusion, however, is that both immigrants and natives should be distinguished by their labor market skills. As noted by Borjas (1995b) and Card (2001), immigration will alter the wage structure—i.e., the relative earnings of different skill groups—only to the extent that the skill composition of immigrants differs from the skill composition of natives. Therefore, when estimating the impact of immigration, it is imperative that the overall influx of immigrants be disaggregated into labor inflows of various skill levels, and it is also imperative that these immigrant inflows be allowed to differentially affect native of workers of different skill levels. A distinguishing feature of U.S. immigration over the past few decades is that, compared to natives, immigrants are disproportionately concentrated in the lowest education groups. Using broad occupation categories to approximate skill groups, Card (2001) exploits cross-city variation in the size and skill content of U.S. immigration inflows between 1985-90, and he finds evidence that immigration did reduce the wages and employment rates of competing native workers (particularly low-skilled natives living in high-immigration cities), although the estimated effects are relatively modest. Using age and education to approximate skill groups, Borjas (2003) exploits national-level variation in the timing and skill content of U.S. immigration over the period 1960-2000, and he produces impacts of immigration that are roughly 2-3 times as large as those estimated by Card (2001). As noted above, however, Ottaviano and Peri (2011) show that changing Borjas's implicit assumptions about the speed of capital adjustment and the substitutability of immigrant and native labor within skill groups can result in immigration ultimately being less harmful for low-skilled native workers and more 
beneficial for other native workers.

Earlier assessments (Friedberg and Hunt 1995; Smith and Edmonston 1997) that immigration's impact on native workers is minimal, even for low-skilled natives, are probably unduly optimistic, because this conclusion is based on studies that for the most part did not adequately account for the skill composition of immigrant flows and the differential effects of these flows on natives in disparate skill groups. Subsequent studies (Card 2001, Borjas 2003) that are careful to make these distinctions tend to find more negative impacts of immigration on low-skilled native workers, but, in our opinion, the estimated effects can still be characterized as being fairly modest. Card (2009) argues that workers who did not finish high school are perfect substitutes for those with a high school diploma, and that this fact accounts for the surprisingly modest impacts of immigration on low-skilled natives. If the relevant skill group includes all those with 12 years of schooling or less, then immigrants no longer differ so dramatically from natives in the fraction of low-skilled workers, and the impact of low-skilled immigration is no longer focused so narrowly on the segment of the native labor force consisting only of high school dropouts.

\section{Conclusion}

At first blush, there are several reasons to expect problems with the economic integration of American immigrants. Unlike other important host countries such as Australia and Canada, the United States makes little or no effort to regulate either the volume or the skill content of immigration flows to fit with current labor market needs. Moreover, a large share of U.S.

immigration is illegal, and the government appears to have limited control over this predominately unskilled flow. Finally, inequality and the returns to skill in the U.S. labor market 
have been rising over the last few decades as large numbers of unskilled immigrants have entered the country. Both in terms of design and implementation, U.S. immigration policy seems haphazard.

Despite all of these warning signs, the labor market performance of U.S. immigrants is surprisingly good. Immigrants have little trouble finding jobs, and this is particularly true of unskilled immigrants. Most immigrants experience substantial earnings growth as they adapt to the American labor market, and the wages they earn are commensurate with their skills. Overall, the U.S.-born second generation has achieved economic parity with mainstream society; for some Hispanic groups, however, this is not the case. On the whole, immigration to the United States has not had large adverse consequences for the labor market opportunities of native workers. Therefore, with regard to the economic integration and labor market impacts of immigration, it is not obvious that the seemingly haphazard nature of U.S. immigration policy has led to unfavorable outcomes.

These findings also suggest that immigration is not a major determinant of U.S. poverty. The relatively modest estimated impacts of immigration on native wages and employment imply that the corresponding effect on the poverty rate of natives is likely to be small, and simulations of this effect by Raphael and Smolensky (2009a) are consistent with such an expectation. High immigrant employment rates and the wage growth associated with assimilation, along with the fact that immigrants remain a small share of the U.S. population, serve to limit the compositional effect of rising immigration on changes in the overall poverty rate. Estimates of this compositional effect indicate that U.S. immigration has played at most a minor role in poverty rate movements over the past several decades (Chapman and Bernstein 2003; Raphael and Smolensky 2009b). 
Despite the explosion in recent years of economic research on the integration and impact of international migrants, many topics are ripe for further investigation. Regarding the labor market assimilation of immigrants, much could be learned from additional studies like Lubotsky (2007) that exploit longitudinal data. Moreover, we need to better understand the relative importance of particular human capital investments and other factors that drive the post-arrival earnings growth of immigrants, such as additional schooling (Betts and Lofstrom 2000), becoming proficient in the host country language (Bleakley and Chin 2004), acquiring citizenship (Bratsberg, Ragan, and Nasir 2002; Mazzolari 2009), and legalization of formerly undocumented immigrants (Kossoudji and Cobb-Clark 2002). With respect to the descendants of immigrants, important and understudied topics include the following: how growing up with an undocumented parent affects the U.S.-born children of immigrants (Bean et al. 2011), why intergenerational convergence seems to be slower for some Hispanic groups (Perlman and Waldinger 1996, 1997; Smith 2003; Telles and Ortiz 2008), and the extent to which selective ethnic attrition distorts inferences regarding the socioeconomic attainment and relative standing of later-generation members of various immigrant groups (Duncan and Trejo 2011b).

In recent years, Hispanic immigrants have increasingly settled in new regions of the United States where formerly they had little or no presence (Fischer and Tienda 2006; Card and Lewis 2007). This so-called “Hispanic Diaspora” creates unique issues for receiving communities and schools that often had little previous experience with immigrants (Fry 2011), and it will be important to monitor the integration of Hispanic immigrants in these new destinations. Moreover, some of these new destinations have sizeable African-American populations (e.g., Atlanta, Georgia, and Raleigh-Durham, North Carolina), which makes it interesting to study whether the labor market impacts of immigration on native workers are 
different in these cities (Card and Lewis 2007). A related and controversial issue is the potential role that low-skill immigration plays in the declining employment and rising incarceration rates of African-American men. Research to date on this question reaches conflicting conclusions (Borjas, Grogger, and Hanson 2011; Raphael and Ronconi 2005), so further work would be useful. Within the general topic of immigration's impact on natives, other questions ripe for further study include how low-skilled immigration affects particular prices (Cortes 2008) and how certain groups of natives respond to such price changes (Furtado and Hock 2010; Cortes and Tessada 2011). Given the important academic and policy issues raised by the large numbers of immigrants received by the United States over the past several decades and the likely continuation of these flows in the foreseeable future, research on U.S. immigration shows no signs of slowing down. 


\section{References}

Alba, Richard D. Ethnic Identity: The Transformation of White America. New Haven, CT: Yale University Press, 1990.

Alba, Richard D., and Islam, Tariqul. "The Case of the Disappearing Mexican Americans: An Ethnic-Identity Mystery.” Population Research and Policy Review, April 2009, 28(2), pp. 109-21.

Alba, Richard D., and Nee, Victor. Rethinking the American Mainstream: Assimilation and Contemporary Immigration. Cambridge, MA: Harvard University Press, 2003.

Antecol, Heather, Peter Kuhn, and Stephen J. Trejo. “Assimilation via Price or Quantities? Sources of Immigrant Earnings Growth in Australia, Canada, and the United States.” Journal of Human Resources, Fall 2006, 41(4), pp. 821-40.

Autor, David, and Katz, Lawrence F. "Changes in the Wage Structure and Earnings Inequality," in Orley Ashenfelter and David Card, eds., Handbook of Labor Economics, vol. 3A. Amsterdam: North Holland, 1999, pp. 1463-1555.

Bean, Frank D.; Lee, Jennifer; Batalova, Jeanne; and Leach, Mark. "Immigration and Fading Color Lines in America,” in Reynolds Farley and John Haaga, eds., The American People: Census 2000. New York: Russell Sage Foundation, 2005.

Bean, Frank D.; Leach, Mark; Brown, Susan K.; Bachmeier, James; and Hipp, John. “The Educational Legacy of Unauthorized Migration: Comparisons across U.S.-Immigrant Groups in How Parents’ Status Affects Their Offspring.” International Migration Review, forthcoming 2011.

Betts, Julian R., and Lofstrom, Magnus. "The Educational Attainment of Immigrants: Trends and Implications,” in George J. Borjas, ed., Issues in the Economics of Immigration. Chicago: University of Chicago Press, 2000, pp. 51-115.

Blau, Francine D., and Kahn, Lawrence M. “Gender and Assimilation among Mexican Americans,” in George J. Borjas, ed., Mexican Immigration to the United States. Chicago: University of Chicago Press, 2007, pp. 57-106.

Bleakley, Hoyt, and Chin, Aimee. "Language Skills and Earnings: Evidence from Childhood Immigrants.” Review of Economics and Statistics, May 2004, 86(2), pp. 481-96.

Bleakley, Hoyt, and Chin, Aimee. "Age at Arrival, English Proficiency, and Social Assimilation among U.S. Immigrants.” American Economic Journal: Applied Economics, January 2010, 2(1), pp. 165-92.

Borjas, George J. “Assimilation, Changes in Cohort Quality, and the Earnings of Immigrants.” 
Journal of Labor Economics, October 1985, 3(4), pp. 463-89.

Borjas, George J. "Self-Selection and the Earnings of Immigrants." American Economic Review, September 1987, 77(4), pp. 531-53.

Borjas, George J. "National Origin and the Skills of Immigrants in the Postwar Period,” in George J. Borjas and Richard B. Freeman, eds., Immigration and the Work Force: Economic Consequences for the United States and Source Areas. Chicago: University of Chicago Press, 1992, pp. 17-47.

Borjas, George J. “The Intergenerational Mobility of Immigrants.” Journal of Labor Economics, January 1993, Part 1, 11(1), pp. 113-35.

Borjas, George J. “The Economics of Immigration.” Journal of Economic Literature, December 1994a, 32(4), pp. 1667-1717.

Borjas, George J. "Long-Run Convergence of Ethnic Skill Differentials: The Children and Grandchildren of the Great Migration.” Industrial and Labor Relations Review, July 1994b, 47(4), pp. 553-73.

Borjas, George J. “Assimilation and Changes in Cohort Quality Revisited: What Happened to Immigrant Earnings in the 1980s?” Journal of Labor Economics, April 1995a, 13(2), pp. 201-45.

Borjas, George J. "The Economic Benefits from Immigration.” Journal of Economic Perspectives, Spring 1995b, 9(2), pp. 3-22.

Borjas, George J. “The Economic Analysis of Immigration,” in Orley Ashenfelter and David Card, eds., Handbook of Labor Economics, vol. 3A. Amsterdam: North Holland, 1999, pp. 1697-1760.

Borjas, George J. "The Labor Demand Curve Is Downward Sloping: Reexamining the Impact of Immigration on the Labor Market.” Quarterly Journal of Economics, November 2003, 118(4), pp. 1335-74.

Borjas, George J. "Native Internal Migration and the Labor Market Impact of Immigration." Journal of Human Resources, Spring 2006, 41(2), pp. 221-58.

Borjas, George J.; Grogger, Jeffrey; and Hanson, Gordon H. "Immigration and AfricanAmericans Employment Opportunities: The Response of Wages, Employment, and Incarceration to Labor Supply Shocks.” Economica, forthcoming 2011.

Borjas, George J., and Katz, Lawrence F. "The Evolution of the Mexican-Born Workforce in the United States,” in George J. Borjas, ed., Mexican Immigration to the United States. Chicago: University of Chicago Press, 2007, pp. 13-55. 
Bratsberg, Bernt; Ragan, James F., and Nasir, Zaffar M. “The Effect of Naturalization on Wage Growth: A Panel Study of Young Male Immigrants.” Journal of Labor Economics, July 2002, 20(3), pp. 568-97.

Card, David. “The Impact of the Mariel Boatlift on the Miami Labor Market.” Industrial and Labor Relations Review, January 1990, 43(2), pp. 245-57.

Card, David. "Immigrant Inflows, Native Outflows, and the Local Labor Market Impacts of Higher Immigration.” Journal of Labor Economics, January 2001, 19(1), pp. 22-64.

Card, David. “Is the New Immigration Really So Bad?” Economic Journal, November 2005, 115(507), pp. 300-23.

Card, David. “Immigration and Inequality.” American Economic Review, May 2009, 99(2), pp. $1-21$.

Card, David, and Lewis, Ethan. "The Diffusion of Mexican Immigrants During the 1990s: Explanations and Impacts,” in George J. Borjas, ed., Mexican Immigration to the United States. Chicago: University of Chicago Press, 2007, pp. 193-227.

Chapman, Jeff, and Bernstein, Jared. “Immigration and Poverty: How Are They Linked?” Monthly Labor Review, April 2003, 126(4), pp. 10-15.

Chiswick, Barry R. "Sons of Immigrants: Are They at an Earnings Disadvantage?” American Economic Review, February 1977, 67(1), pp. 376-80.

Chiswick, Barry R. “The Effect of Americanization on the Earnings of Foreign-Born Men.” Journal of Political Economy, October 1978, 86(5): 897-921.

Chiswick, Barry R. Illegal Aliens: Their Employment and Employers. Kalamazoo, Michigan: W. E. Upjohn Institute for Employment Research, 1988.

Chiswick, Barry R.; Cohen, Yinon; and Zach, Tzippi. “The Labor Market Status of Immigrants: Effects of the Unemployment Rate at Arrival and Duration of Residence.” Industrial and Labor Relations Review, January 1997, 50(2), pp. 289-303.

Chiswick, Barry R., and Miller, Paul W. “The Endogeneity between Language and Earnings: International Analyses.” Journal of Labor Economics, April 1995, 13(2), pp. 246-88.

Cortes, Patricia. “The Effect of Low-Skilled Immigration on U.S. Prices: Evidence from CPI Data.” Journal of Political Economy, June 2008, 116(3), pp. 381-422.

Cortes, Patricia, and Tessada, Jose. "Low-Skilled Immigration and the Labor Supply of Highly Skilled Women.” American Economic Journal: Applied Economics, forthcoming 2011.

Davila, Alberto; Bohara, Alok K.; and Saenz, Rogelio. “Accent Penalties and the Earnings of 
Mexican Americans.” Social Science Quarterly, December 1993, 74(4), pp. 902-16.

del Pinal, Jorge H. Race and Ethnicity in Census 2000. Census 2000 Testing, Experimentation, and Evaluation Program: Topic Report No. 9. Washington, DC: U.S. Census Bureau, March 2004.

Donato, Katharine M., and Massey, Douglas S. "Effect of the Immigration Reform and Control Act on the Wages of Mexican Migrants.” Social Science Quarterly, September 1993, 74(3), pp. 523-41.

Duncan, Brian; Hotz, V. Joseph; and Trejo, Stephen J. "Hispanics in the U.S. Labor Market," in Marta Tienda and Faith Mitchell, eds., Hispanics and the Future of America. Washington, DC: Washington, DC: National Academies Press, 2006.

Duncan, Brian, and Trejo, Stephen J. "Ethnic Identification, Intermarriage, and Unmeasured Progress by Mexican Americans," in George J. Borjas, ed., Mexican Immigration to the United States. Chicago: University of Chicago Press, 2007, pp. 227-69.

Duncan, Brian, and Trejo, Stephen J. "Ancestry versus Ethnicity: The Complexity and Selectivity of Mexican Identification in the United States." Research in Labor Economics, 2009a, vol. 29 (Ethnicity and Labor Market Outcomes, edited by Amelie F. Constant, Konstantinos Tatsiramos, and Klaus F. Zimmerman), pp. 31-66.

Duncan, Brian, and Trejo, Stephen J. "Selectivity and Immigrant Employment.” Manuscript. Austin: University of Texas, May 2009b.

Duncan, Brian, and Trejo, Stephen J. "Intermarriage and the Intergenerational Transmission of Ethnic Identity and Human Capital for Mexican Americans.” Journal of Labor Economics, April 2011a, 29(2), pp. 195-227.

Duncan, Brian, and Trejo, Stephen J. "Tracking Intergenerational Progress for Immigrant Groups: The Problem of Ethnic Attrition.” American Economic Review, May 2011b, 101(3), pp. 603-08.

Duncan, Brian, and Trejo, Stephen J. "Who Remains Mexican? Selective Ethnic Attrition and the Intergenerational Progress of Mexican Americans," in David L. Leal and Stephen J. Trejo, eds., Latinos and the Economy: Integration and Impact in Schools, Labor Markets, and Beyond. New York: Springer, 2011c, pp. 285-320..

Eschbach, Karl. "The Enduring and Vanishing American Indian: American Indian Population Growth and Intermarriage in 1990.” Ethnic and Racial Studies, January 1995, 18(1), pp. 89-108.

Eschbach, Karl; Supple, Khalil; and Snipp, C. Matthew. "Changes in Racial Identification and the Educational Attainment of American Indians, 1970-1990.” Demography, February 1998, 35(1), pp. 35-43. 
Farley, Reynolds. "Blacks, Hispanics, and White Ethnic Groups: Are Blacks Uniquely Disadvantaged?” American Economic Review, May 1990, 80(2), pp. 237-41.

Fischer, Mary J., and Tienda, Marta. "Redrawing Spatial Color Lines: Hispanic Metropolitan Dispersal, Segregation, and Economic Opportunity,” in Marta Tienda and Faith Mitchell, eds., Hispanics and the Future of America. Washington, DC: National Academies Press, 2006, pp. 100-37.

Friedberg, Rachel M., and Hunt, Jennifer. "The Impact of Immigrants on Host country Wages, Employment and Growth.” Journal of Economic Perspectives, Spring 1995, 9(2), pp. 2344.

Fry, Richard. "The Hispanic Diaspora and the Public Schools: Educating Hispanics,” in David L. Leal and Stephen J. Trejo, eds., Latinos and the Economy: Integration and Impact in Schools, Labor Markets, and Beyond. New York: Springer, 2011, pp. 15-36.

Funkhouser, Edward. “Convergence in Employment Rates of Immigrants.” In George J. Borjas, ed., Issues in the Economics of Immigration. Chicago: University of Chicago Press, 2000.

Funkhouser, Edward; and Trejo, Stephen J. "Labor Market Outcomes of Female Immigrants in the United States,” in James P. Smith and Barry Edmonston, eds., The Immigration Debate: Studies on the Economic, Demographic, and Fiscal Effects of Immigration. Washington, DC: National Academy Press, 1998, pp. 239-88.

Furtado, Delia. "Human Capital and Interethnic Marriage Decisions.” Discussion Paper no. 1989. Bonn, Germany: IZA, February 2006.

Furtado, Delia, and Hock, Heinrich. "Low Skilled Immigration and Work-Fertility Tradeoffs Among High Skilled US Natives.” American Economic Review, May 2010, 100(2): pp. 224-28.

Gans, Herbert J. "Second-Generation Decline: Scenarios for the Economic and Ethnic Futures of the Post-1965 American Immigrants.” Ethnic and Racial Studies, April 1992, 15(2), pp. 173-92.

Gordon, Milton M. Assimilation in American Life: The Role of Race, Religion, and National Origins. New York: Oxford University Press, 1964.

Grieco, Elizabeth M., and Cassidy, Rachel C. Overview of Race and Hispanic Origin. Census 2000 Brief C2KBR/01-1. Washington, DC: U.S. Census Bureau, March 2001.

Grogger, Jeffrey, and Trejo, Stephen J. Falling Behind or Moving Up? The Intergenerational Progress of Mexican Americans. San Francisco: Public Policy Institute of California, 2002. 
Hout, Michael, and Goldstein, Joshua R. "How 4.5 Million Irish Immigrants Became 40 Million Irish Americans: Demographic and Subjective Aspects of the Ethnic Composition of White Americans.” American Sociological Review, February 1994, 59(1), pp. 64-82.

Huntington, Samuel P. Who Are We? The Challenges to America's National Identity. New York: Simon and Schuster, 2004.

Jaeger, David A. "Reconciling the Old and New Census Bureau Education Questions: Recommendations for Researchers.” Journal of Business and Economics Statistics, July 1997, 15(3), pp. 300-09.

Jasso, Guillermina, and Rosenzweig, Mark R. "What's in a Name? Country-of-Origin Influences on the Earnings of Immigrants in the United States,” in Oded Stark, ed., Research in Human Capital and Development, Vol. 4. Greenwich, Conn.: JAI Press, 1986, pp. 75-106.

Jones, Nicholas A., and Symens Smith, Amy. The Two or More Races Population. Census 2000 Brief C2KBR/01-6. Washington, DC: U.S. Census Bureau, November 2001.

Juhn, Chinhui. "Decline of Male Labor Market Participation: The Role of Declining Market Opportunities.” Quarterly Journal of Economics, February 1992, 107(1), pp. 79-121.

Kossoudji, Sherrie A., and Cobb-Clark, Deborah A. "Coming out of the Shadows: Learning about Legal Status and Wages from the Legalized Population.” Journal of Labor Economics, July 2002, 20(3), pp. 598-628.

Levy, Frank, and Murnane, Richard J. "U.S. Earnings Levels and Earnings Inequality: A Review of Recent Trends and Proposed Explanations.” Journal of Economic Literature, September 1992, 30(3), pp. 1333-81.

Lewis, Ethan. "Local Open Economies Within the U.S.: How Do Industries Respond to Immigration?” Working Paper No. 04-1. Federal Reserve Bank of Philadelphia, December 2003.

Lewis, Ethan. “Immigration, Skill Mix, and Capital-Skill Complementarity.” Quarterly Journal of Economics, forthcoming 2011.

Lichter, Daniel T., and Qian, Zhenchao. "Marriage and Family in a Multiracial Society,” in Reynolds Farley and John Haaga, eds., The American People: Census 2000. New York: Russell Sage Foundation, 2005, pp. 169-200.

Lieberson, Stanley, and Waters, Mary C. From Many Strands: Ethnic and Racial Groups in Contemporary America. New York: Russell Sage Foundation, 1988.

Lowenstein, Roger. “The Immigration Equation.” New York Times Magazine, July 9, 2006, pp. 
36-43 and 69-71.

Lubotsky, Darren. “Chutes or Ladders? A Longitudinal Analysis of Immigrant Earnings.” Journal of Political Economy, October 2007, 115(5), pp. 820-67.

Mazzolari, Francesca. “Dual Citizenship Rights: Do They Make More and Richer Citizens?” Demography, February 2009, 46 (1), pp. 169-91.

Massey, Douglas S. "Do Undocumented Migrants Earn Lower Wages than Legal Immigrants? New Evidence from Mexico.” International Migration Review, Summer 1987, 21(2), pp. 236-74.

McManus, Walter; Gould, William; and Welch, Finis. "Earnings of Hispanic Men: The Role of English Language Proficiency.” Journal of Labor Economics, April 1983, 1(2), pp. 10130.

Neidert, Lisa J., and Farley, Reynolds. “Assimilation in the United States: An Analysis of Ethnic and Generation Differences in Status and Achievement.” American Sociological Review, December 1985, 50(6), pp. 840-50.

Ottaviano, Gianmarco I.P., and Peri, Giovanni. "Rethinking the Effects of Immigration on Wages.” Journal of the European Economic Association, forthcoming 2011.

Passel, Jeffrey. "Mexican Immigration to the U.S.: The Latest Estimates.” Manuscript. Washington, DC: Migration Policy Institute, 2004.

Passel, Jeffrey. "Unauthorized Migrants in the United States: Estimates, Methods, and Characteristics.” Social, Employment, and Migration Working Paper no. 57. Paris: Organization for Economic Cooperation and Development, September 2007.

Perez, Anthony D., and Hirschman, Charles. "The Changing Racial and Ethnic Composition of the US Population: Emerging American Identities.” Population and Development Review, March 2009, 35(1), pp. 1-51.

Peri, Giovanni. "Immigrants, Skills, and Wages: Measuring the Economic Gains from Immigration.” Immigration Policy in Focus, 5(3). Washington, DC: American Immigration Law Foundation, March 2006a.

Peri, Giovanni. "Rethinking the Effects of Immigration on Wages: New Data and Analysis from 1990-2004.” Immigration Policy in Focus, 5(8). Washington, DC: American Immigration Law Foundation, October 2006b.

Peri, Giovanni. “How Immigrants Affect California Employment and Wages.” California Counts: Population Trends and Profiles, 8(3). San Francisco: Public Policy Institute of California, February 2007. 
Perlmann, Joel. Italians Then, Mexicans Now: Immigrant Origins and Second-Generation Progress, 1890-2000. New York: Russell Sage Foundation, 2005.

Perlmann, Joel, and Waldinger, Roger. "The Second Generation and the Children of the Native Born: Comparisons and Refinements.” Working Paper no. 174. Annandale-on-Hudson, NY: Jerome Levy Economics Institute, November 1996.

Perlmann, Joel, and Waldinger, Roger. "Second Generation Decline? Children of Immigrants, Past and Present-A Reconsideration.” International Migration Review, Winter 1997, 31(4), pp. 893-922.

Perlmann, Joel, and Waters, Mary C. “Intermarriage and Multiple Identities,” in Mary C. Waters and Reed Udea, eds., The New Americans: A Guide to Immigration Since 1965. Cambridge, MA: Harvard University Press, 2007, pp. 110-23.

Portes, Alejandro, and Rumbaut, Ruben G. Legacies: The Story of the Immigrant Second Generation. Berkeley, CA: University of California Press, 2001.

Portes, Alejandro, and Zhou, Min. "The New Second Generation: Segmented Assimilation and Its Variants Among Post-1965 Immigrant Youth.” Annals of the American Academy of Political and Social Science, November 1993, 530, pp. 74-96.

Ramakrishnan, S. Karthick. “Second-Generation Immigrants? The '2.5' Generation in the United States.” Social Science Quarterly, June 2004, 85(2), pp. 380-99.

Raphael, Steven, and Ronconi, Lucas. "The Effects of Labor Market Competition with Immigrants on the Wages and Employment of Natives: What Does Existing Research Tell Us?” Du Bois Review, September 2007, 4(2), pp. 413-32.

Raphael, Steven, and Ronconi, Lucas. "Reconciling National and Regional Estimates of the Effects of Immigration on U.S. Labor Markets: The Confounding Effects of Native Male Incarceration Trends.” Manuscript. Berkeley: University of California, October 2005.

Raphael, Steven, and Smolensky, Eugene. "Immigration and Poverty in the United States." American Economic Review, May 2009a, 99(2), pp. 41-44.

Raphael, Steven, and Smolensky, Eugene. "Immigration and Poverty in the United States.” Focus, Fall 2009b, 26(2), pp. 27-31.

Rivera-Batiz, Francisco L. "Undocumented Workers in the Labor Market: An Analysis of the Earnings of Legal and Illegal Mexican Immigrants in the United States.” Journal of Population Economics, 1999, 12(1): 91-116.

Rumbaut, Ruben G. "The Crucible Within: Ethnic Identity, Self-Esteem, and Segmented Assimilation Among Children of Immigrants.” International Migration Review, Winter 1994, 28(4), pp. 748-94. 
Rumbaut, Ruben G. “Ages, Life Stages, and Generational Cohorts: Decomposing the Immigrant First and Second Generations in the United States.” International Migration Review, Fall 2004, 38(3), pp. 1160-1205.

Sakamoto, Arthur; Goyette, Kimberly A.; and Kim, ChangHwan. "Socioeconomic Attainments of Asian Americans.” Annual Review of Sociology, 2009, 35, pp. 255-76.

Schoeni, Robert. “Labor Market Assimilation of Immigrant Women.” Industrial and Labor Relations Review, April 1998, 51(3), pp. 483-504.

Smith, James P. “Assimilation across the Latino Generations.” American Economic Review, May 2003, 93(2), pp. 315-319.

Smith, James P. “Immigrants and the Labor Market.” Journal of Labor Economics, April 2006, 24(2): 203-33.

Smith, James P., and Edmonston, Barry, eds. The New Americans: Economic Demographic, and Fiscal Effects of Immigration. Washington, DC: National Academy Press, 1997.

Snipp, C. Matthew. American Indians: The First of this Land. New York: Russell Sage Foundation, 1989.

Sowell, Thomas. “Three Black Histories,” in Thomas Sowell, ed., Essays and Data on American Ethnic Groups. Washington, DC: Urban Institute, 1978, pp. 7-64.

Sullivan, Dennis H., and Ziegert, Andrea L. "Hispanic Immigrant Poverty: Does Ethnic Origin Matter?” Population Research and Policy Review, December 2008, 27(6), pp. 667-87.

Telles, Edward E., and Ortiz, Vilma. Generations of Exclusion: Mexican Americans, Assimilation, and Race. New York: Russell Sage Foundation, 2008.

Trejo, Stephen J. “Why Do Mexican Americans Earn Low Wages?” Journal of Political Economy, December 1997, 105(6), pp. 1235-68.

Trejo, Stephen J. "Intergenerational Progress of Mexican-Origin Workers in the U.S. Labor Market.” Journal of Human Resources, Summer 2003, 38(3), pp. 467-89.

U.S. Bureau of the Census. 1970 Census of Population and Housing, Evaluation and Research Program: Accuracy of Data for Selected Population Characteristics as Measured by Reinterviews. Washington, DC: U.S. Government Printing Office, 1974.

Waters, Mary C. Ethnic Options: Choosing Identities in America. Berkeley, CA: University of California Press, 1990.

Waters, Mary C. "Ethnic and Racial Identities of Second-Generation Black Immigrants in New 
York City.” International Migration Review, Winter 1994, 28(4), pp. 795-820.

Waters, Mary C. Black Identities: West Indian Immigrant Dreams and American Realities. New York: Russell Sage Foundation, 1999.

Welch, Finis. “The Employment of Black Men.” Journal of Labor Economics, January 1990, 8(1, part 2), pp. S26-S74.

White, Halbert. "A Heteroskedasticity-Consistent Covariance Matrix Estimator and a Direct test for Heteroskedasticity.” Econometrica, May 1980, 48(4), pp. 817-38. 
Table 1: Percentage Distributions and Average Education of U.S. Men, Ages 25-59, by Nativity and Race/Ethnicity

\begin{tabular}{|c|c|c|c|}
\hline & $\begin{array}{l}\text { Percent } \\
\text { of Total }\end{array}$ & $\begin{array}{c}\text { Sample } \\
\text { Size }\end{array}$ & $\begin{array}{c}\text { Average } \\
\text { Education }\end{array}$ \\
\hline \multicolumn{4}{|l|}{ A. By Nativity } \\
\hline U.S.-born & 80.6 & $1,674,940$ & 13.5 \\
\hline \multicolumn{4}{|l|}{ Foreign-born: } \\
\hline Born abroad of American parent & 0.9 & 17,379 & 13.9 \\
\hline Child immigrant & 3.8 & 65,046 & 12.6 \\
\hline Adult immigrant & 14.7 & 236,327 & 11.8 \\
\hline All nativity groups & $100.0 \%$ & $1,993,692$ & 13.2 \\
\hline
\end{tabular}

\section{B. By Nativity and Race/Ethnicity}

U.S.-born

Hispanic

Non-Hispanic:

White

Black

Asian

Other race

All race/ethnic groups

6.3

6.3

85,483

12.6

79.5

$1,402,011$

13.7

11.3

140,066

12.7

1.0

15,265

14.8

1.9

32,115

13.0

$100.0 \%$

$1,674,940$

13.5

Born abroad of American parent

Hispanic

14.4

2,043

12.5

Non-Hispanic:

White

67.2

12,567

14.2

Black

5.8

767

13.7

Asian

7.4

1,106

14.1

Other race

5.2

896

14.0

All race/ethnic groups

$100.0 \%$

17,379

13.9

\section{Child immigrant}

Hispanic

53.5

32,242

11.2

Non-Hispanic:

White

19.2

14,829

14.0

Black

5.5

3,041

13,937

13.8

20.3

997

14.6

Other race

All race/ethnic groups

\section{Adult immigrant}

Hispanic

Non-Hispanic:

White

Black

1.4

65,046

13.3

$100.0 \%$

12.6

52.9

113,278

9.7

16.1

44,112

14.3

7.3

16,114

13.3

Asian

22.4

59,532

14.5

Other race

1.4

3,291

12.9

All race/ethnic groups

Source: 2005-2007 American Community Survey data.

Note: The sample includes men ages 25-59 who do not reside in institutions. Among foreign-born individuals who were not born to an American parent, "child immigrants" are those who arrived in the United States before the age of 16, and "adult immigrants" are those who arrived at age 16 or later. Sampling weights were used in the calculations. 


\section{Table 2: Educational Distributions (\%) of U.S. Men, Ages 25-59, by Nativity and Race/Ethnicity}

\author{
A. By Nativity \\ U.S.-born \\ Foreign-born: \\ Born abroad of American parent \\ Child immigrant \\ Adult immigrant
}

\section{B. By Nativity and Race/Ethnicity}

\section{U.S.-born}

Hispanic

Non-Hispanic:

White

Black

Asian

Other race

\section{Born abroad of American parent}

Hispanic

Non-Hispanic:

White

Black

Asian

Other race

\section{Child immigrant}

Hispanic

Non-Hispanic:

White

Black

Asian

Other race

\section{Adult immigrant}

Hispanic

Non-Hispanic:

White

Black

Asian

Other race
Years of Education:

\begin{tabular}{|c|c|c|c|c|}
\hline \multicolumn{4}{|c|}{ Years of Education: } & \multirow{2}{*}{$\begin{array}{l}\text { All Educ. } \\
\text { Levels }\end{array}$} \\
\hline$<12$ & 12 & $13-15$ & $16+$ & \\
\hline 7.8 & 33.0 & 29.7 & 29.4 & $100.0 \%$ \\
\hline 6.4 & 23.7 & 32.3 & 37.6 & $100.0 \%$ \\
\hline 19.8 & 29.6 & 24.7 & 25.9 & $100.0 \%$ \\
\hline 30.3 & 26.7 & 15.1 & 27.9 & $100.0 \%$ \\
\hline
\end{tabular}

15.7

31.6

42.0

16.4

35.1

30.8

16.3

$100.0 \%$

6.6

29.6

32.3

$100.0 \%$

29.9

15.8

$100.0 \%$

3.0

26.3

33.7

$100.0 \%$

11.4

29.8

26.1

54.2

$100.0 \%$

19.3

22.5

32.8

36.6

32.8

38.1

24.8

$100.0 \%$

4.0

29.8

20.0

20.9

32.6

35.2

20.6

40.7

$100.0 \%$

$28.8 \quad 100.0 \%$

$41.3 \quad 100.0 \%$

$37.3 \quad 100.0 \%$

3.7

$\begin{array}{ll}6.4 & 26.3 \\ 4.1 & 28.9\end{array}$

18.2

3.8

28.3

28.8

37.3

27.7

31.6

11.6

$100.0 \%$

10.4

30.1

11.6

38.5

29.7

$100.0 \%$

$100.0 \%$

50.3

$100.0 \%$

29.7

$100.0 \%$

49.3

24.4

20.1

26.1

15.9

18.9

\section{$9.1 \quad 100.0 \%$}

48.4

30.5

56.6

33.0
$100.0 \%$

$100.0 \%$

$100.0 \%$

$100.0 \%$

Source: 2005-2007 American Community Survey data.

Note: The reported figures show the percentage of individuals from each nativity group and race/ethnicity who fall within a particular educational category. The sample includes men ages 25-59 who do not reside in institutions (see Table 1 for sample sizes). Among foreign-born individuals who were not born to an American parent, "child immigrants" are those who arrived in the United States before the age of 16, and "adult immigrants" are those who arrived at age 16 or later. Sampling weights were used in the calculations. 


\section{Table 3: Employment Rates (\%) of U.S. Men, Ages 25-59, by Nativity and Education Level}

\begin{tabular}{|c|c|c|c|c|c|}
\hline & & Years & ucation: & & All Educ. \\
\hline & $<12$ & 12 & $13-15$ & $16+$ & Levels \\
\hline U.S.-born & $\begin{array}{l}71.9 \\
(0.13)\end{array}$ & $\begin{array}{l}87.7 \\
(0.04)\end{array}$ & $\begin{array}{l}91.9 \\
(0.04)\end{array}$ & $\begin{array}{l}95.8 \\
(0.03)\end{array}$ & $\begin{array}{l}90.1 \% \\
(0.02)\end{array}$ \\
\hline Foreign-born: & & & & & \\
\hline Born abroad of American parent & $\begin{array}{l}82.1 \\
(1.26)\end{array}$ & $\begin{array}{l}90.7 \\
(0.47)\end{array}$ & $\begin{array}{l}92.9 \\
(0.34)\end{array}$ & $\begin{array}{l}96.0 \\
(0.24)\end{array}$ & $\begin{array}{l}92.8 \\
(0.20)\end{array}$ \\
\hline Child immigrant & $\begin{array}{l}88.7 \\
(0.29)\end{array}$ & $\begin{array}{l}91.0 \\
(0.21)\end{array}$ & $\begin{array}{l}92.9 \\
(0.20)\end{array}$ & $\begin{array}{l}95.3 \\
(0.15)\end{array}$ & $\begin{array}{l}92.1 \\
(0.11)\end{array}$ \\
\hline Adult immigrant & $\begin{array}{l}92.4 \\
(0.10)\end{array}$ & $\begin{array}{l}92.9 \\
(0.11)\end{array}$ & $\begin{array}{l}92.3 \\
(0.14)\end{array}$ & $\begin{array}{l}93.8 \\
(0.09)\end{array}$ & $\begin{array}{l}92.9 \\
(0.05)\end{array}$ \\
\hline
\end{tabular}

Source: 2005-2007 American Community Survey data.

Note: The reported figures give the percentage of individuals who were employed at any time during the twelve months preceding the survey date. Standard errors are shown in parentheses. The sample includes men ages 25-59 who do not reside in institutions (see Table 1 for sample sizes). Among foreign-born individuals who were not born to an American parent, "child immigrants" are those who arrived in the United States before the age of 16, and "adult immigrants" are those who arrived at age 16 or later. Sampling weights were used in the calculations. 


\section{Table 4: Employment Regressions}

\begin{tabular}{|c|c|c|c|c|}
\hline \multirow[b]{3}{*}{ Regressor } & \multicolumn{4}{|c|}{ Years of Education: } \\
\hline & \multicolumn{2}{|c|}{ Less than 12} & \multicolumn{2}{|c|}{12 or More } \\
\hline & $(1)$ & $(2)$ & (1) & $(2)$ \\
\hline \multicolumn{5}{|l|}{ U.S.-born (reference group) } \\
\hline \multicolumn{5}{|l|}{ Foreign-born: } \\
\hline Born abroad of American parent & $\begin{array}{l}.084 \\
(.015)\end{array}$ & $\begin{array}{l}.084 \\
(.015)\end{array}$ & $\begin{array}{l}.004 \\
(.002)\end{array}$ & $\begin{array}{l}.004 \\
(.002)\end{array}$ \\
\hline Child immigrant & $\begin{array}{l}.133 \\
(.004)\end{array}$ & $\begin{array}{l}.133 \\
(.004)\end{array}$ & $\begin{array}{l}.003 \\
(.001)\end{array}$ & $\begin{array}{l}.002 \\
(.001)\end{array}$ \\
\hline Adult immigrant & $\begin{array}{l}.186 \\
(.002)\end{array}$ & & $\begin{array}{l}.008 \\
(.0008)\end{array}$ & \\
\hline $0-2$ years in U.S. & & $\begin{array}{l}.153 \\
(.005)\end{array}$ & & $\begin{array}{l}-.084 \\
(.004)\end{array}$ \\
\hline 3-5 years in U.S. & & $\begin{array}{l}.188 \\
(.004)\end{array}$ & & $\begin{array}{l}-.009 \\
(.002)\end{array}$ \\
\hline 6-10 years in U.S. & & $\begin{array}{l}.178 \\
(.003)\end{array}$ & & $\begin{array}{l}.014 \\
(.001)\end{array}$ \\
\hline $11-15$ years in U.S. & & $\begin{array}{l}.181 \\
(.004)\end{array}$ & & $\begin{array}{l}.021 \\
(.002)\end{array}$ \\
\hline $16-20$ years in U.S. & & $\begin{array}{l}.193 \\
(.004)\end{array}$ & & $\begin{array}{l}.026 \\
(.002)\end{array}$ \\
\hline Over 20 years in U.S. & & $\begin{array}{l}.203 \\
(.004)\end{array}$ & & $\begin{array}{l}.027 \\
(.002)\end{array}$ \\
\hline $\begin{array}{l}\text { Education: } \\
12 \text { years (reference group) }\end{array}$ & & & & \\
\hline $13-15$ years & & & $\begin{array}{l}.037 \\
(.0007)\end{array}$ & $\begin{array}{l}.037 \\
(.0007)\end{array}$ \\
\hline 16 or more years & & & $\begin{array}{l}.074 \\
(.0006)\end{array}$ & $\begin{array}{l}.074 \\
(.0006)\end{array}$ \\
\hline
\end{tabular}

Source: 2005-2007 American Community Survey data.

Note: The reported figures are estimated coefficients from least squares regressions, run separately by education category, in which the dependent variable is a dummy identifying individuals who were employed at any time during the twelve months preceding the survey date. Heteroskedasticity-robust standard errors are shown in parentheses. The sample includes men ages 25-59 who do not reside in institutions (see Table 1 for sample sizes). All regressions include controls for age, geographic location, and survey year. Among foreign-born individuals who were not born to an American parent, "child immigrants" are those who arrived in the United States before the age of 16, and "adult immigrants" are those who arrived at age 16 or later. Sampling weights were used in the calculations. 


\section{Table 5: Employment Differentials (Relative to U.S.-born, Non-Hispanic Whites), by Nativity, Race/Ethnicity, and Education Level}

\begin{tabular}{|c|c|c|}
\hline \multirow[b]{2}{*}{ Regressor } & \multicolumn{2}{|c|}{ Years of Education: } \\
\hline & Less than 12 & 12 or More \\
\hline \multicolumn{3}{|l|}{ U.S.-born } \\
\hline Hispanic & $\begin{array}{l}.012 \\
(.005)\end{array}$ & $\begin{array}{l}-.017 \\
(.001)\end{array}$ \\
\hline \multicolumn{3}{|c|}{$\begin{array}{l}\text { Non-Hispanic: } \\
\text { White (reference group) }\end{array}$} \\
\hline Black & $\begin{array}{l}-.152 \\
(.005)\end{array}$ & $\begin{array}{l}-.076 \\
(.001)\end{array}$ \\
\hline Asian & $\begin{array}{l}-.035 \\
(.027)\end{array}$ & $\begin{array}{l}-.027 \\
(.003)\end{array}$ \\
\hline Other race & $\begin{array}{l}-.100 \\
(.010)\end{array}$ & $\begin{array}{l}-.065 \\
(.003)\end{array}$ \\
\hline \multicolumn{3}{|c|}{ Adult immigrant } \\
\hline Hispanic & $\begin{array}{l}.166 \\
(.003)\end{array}$ & $\begin{array}{l}.020 \\
(.001)\end{array}$ \\
\hline \multicolumn{3}{|c|}{ Non-Hispanic: } \\
\hline White & $\begin{array}{l}.124 \\
(.009)\end{array}$ & $\begin{array}{l}-.005 \\
(.002)\end{array}$ \\
\hline Black & $\begin{array}{l}.126 \\
(.011)\end{array}$ & $\begin{array}{l}-.011 \\
(.003)\end{array}$ \\
\hline Asian & $\begin{array}{l}.106 \\
(.007)\end{array}$ & $\begin{array}{l}-.030 \\
(.002)\end{array}$ \\
\hline Other race & $\begin{array}{l}.160 \\
(.013)\end{array}$ & $\begin{array}{l}-.007 \\
(.006)\end{array}$ \\
\hline
\end{tabular}

Source: 2005-2007 American Community Survey data.

Note: The reported figures are estimated coefficients from least squares regressions, run separately by education category, in which the dependent variable is a dummy identifying individuals who were employed at any time during the twelve months preceding the survey date. Heteroskedasticity-robust standard errors are shown in parentheses. The sample includes men ages 25-59 who do not reside in institutions (see Table 1 for sample sizes). All regressions include controls for age, geographic location, and survey year, and the regression for those with 12 or more years of education also includes dummies identifying individuals with 13-15 and 16 or more years of education. Among foreign-born individuals who were not born to an American parent, "child immigrants" are those who arrived in the United States before the age of 16, and "adult immigrants" are those who arrived at age 16 or later. Sampling weights were used in the calculations. 


\section{Table 6: English Proficiency Distributions (\%) of U.S. Men, Ages 25-59, by Nativity and Education Level}

\author{
A. By Nativity \\ U.S.-born \\ Foreign-born: \\ Born abroad of American parent \\ Child immigrant \\ Adult immigrant
}

\section{B. By Nativity and Education Level}

\section{U.S.-born}

Less than 12 years of education

12 or more years of education

Born abroad of American parent

Less than 12 years of education

12 or more years of education

\section{Child immigrant}

Less than 12 years of education

12 or more years of education

\section{Adult immigrant}

Less than 12 years of education

12 or more years of education

\begin{tabular}{ccc}
\multicolumn{3}{c}{ Speaks English: } \\
\hline Only & $\begin{array}{c}\text { Very Well } \\
\text { or Well }\end{array}$ & $\begin{array}{c}\text { Not Well } \\
\text { or Not at All }\end{array}$ \\
\hline
\end{tabular}

All Levels of Proficiency

93.4

6.3

0.4

$100.0 \%$

76.0

21.2

2.8

11.1

$100.0 \%$

24.0

64.9

35.3

$100.0 \%$

$100.0 \%$

88.2

10.3

1.5

$100.0 \%$

93.8

5.9

0.3

$100.0 \%$

44.4

35.9

19.8

$100.0 \%$

78.2

20.2

1.7

$100.0 \%$

6.6

57.9

35.5

$100.0 \%$

28.3

66.6

5.1

$100.0 \%$

$\begin{array}{rrrr}4.2 & 30.6 & 65.3 & 100.0 \% \\ 14.1 & 63.6 & 22.3 & 100.0 \%\end{array}$

Source: 2005-2007 American Community Survey data.

Note: The reported figures show the percentage of individuals from each nativity group and education level who fall within a particular category for self-reported proficiency at speaking English. The sample includes men ages 25-59 who do not reside in institutions (see Table 1 for sample sizes). Among foreign-born individuals who were not born to an American parent, "child immigrants" are those who arrived in the United States before the age of 16, and "adult immigrants" are those who arrived at age 16 or later. Sampling weights were used in the calculations. 


\section{Table 7: Wage Regressions}

Years of Education:

(1)
(3)

$\begin{array}{lll}-.012 & -.011 & .042 \\ (.028) & (.028) & (.028) \\ -.068 & -.071 & .023 \\ (.008) & (.008) & (.011) \\ -.186 & & \\ (.005) & & \\ & -.343 & -.120 \\ & (.012) & (.014) \\ & -.288 & -.091 \\ & (.010) & (.012) \\ & -.216 & -.047 \\ & (.007) & (.010) \\ & -. .179 & -.031 \\ & (.008) & (.011) \\ & -.136 & -.0003 \\ & (.009) & (.011) \\ & -.080 & .040 \\ & (.007) & (.010)\end{array}$

$\begin{array}{lll}-.031 & -.031 & -.013 \\ (.007) & (.007) & (.007) \\ -.029 & -.030 & .038 \\ (.004) & (.004) & (.004) \\ -.208 & & \\ (.002) & & \\ & -.326 & -.125 \\ & (.008) & (.009) \\ & -.316 & -.128 \\ & (.006) & (.007) \\ & -.213 & -.048 \\ & (.004) & (.005) \\ & -.183 & -.032 \\ & (.005) & (.006) \\ & -.188 & -.047 \\ & (.005) & (.006) \\ & -.131 & -.012 \\ & (.004) & (.005)\end{array}$

U.S.-born (reference group)

Foreign-born:

Born abroad of American parent

Child immigrant

Adult immigrant

0-2 years in U.S.

3-5 years in U.S.

6-10 years in U.S.

11-15 years in U.S.

16-20 years in U.S.

Over 20 years in U.S.

Speaks English:

Only (reference group)

Very well

Well

Not well

Not at all

Education:

12 years (reference group)

13-15 years

$\begin{array}{lll}.169 & .168 & .158 \\ (.002) & (.002) & (.002) \\ .591 & .592 & .573 \\ (.002) & (.002) & (.002)\end{array}$

16 or more years

Source: 2005-2007 American Community Survey data.

Note: The reported figures are estimated coefficients from least squares regressions, run separately by education category, in which the dependent variable is the natural logarithm of average hourly earnings during the twelve months preceding the survey date. Heteroskedasticity-robust standard errors are shown in parentheses. The sample includes men ages 25-59 who do not reside in institutions and who report average hourly earnings between $\$ 1$ and $\$ 1,000$. The sample sizes are 155,667 for those with less than 12 years of education and 1,647,100 for those with 
12 or more years of education. All regressions include controls for age, geographic location, and survey year. Among foreign-born individuals who were not born to an American parent, "child immigrants" are those who arrived in the United States before the age of 16, and "adult immigrants" are those who arrived at age 16 or later. Sampling weights were used in the calculations. 
Table 8: Wage Differentials (Relative to U.S.-born, Non-Hispanic Whites), by Nativity, Race/Ethnicity, and Education Level

\begin{tabular}{|c|c|c|c|c|}
\hline \multirow[b]{3}{*}{ Regressor } & \multicolumn{4}{|c|}{ Years of Education: } \\
\hline & \multicolumn{2}{|c|}{ Less than 12} & \multicolumn{2}{|c|}{12 or More } \\
\hline & $(1)$ & $(2)$ & $(1)$ & $(2)$ \\
\hline \multicolumn{5}{|l|}{ U.S.-born } \\
\hline Hispanic & $\begin{array}{l}-.135 \\
(.009)\end{array}$ & $\begin{array}{l}-.128 \\
(.011)\end{array}$ & $\begin{array}{l}-.105 \\
(.003)\end{array}$ & $\begin{array}{l}-.077 \\
(.004)\end{array}$ \\
\hline \multicolumn{5}{|l|}{$\begin{array}{l}\text { Non-Hispanic: } \\
\text { White (reference group) }\end{array}$} \\
\hline Black & $\begin{array}{l}-.186 \\
(.010)\end{array}$ & $\begin{array}{l}-.187 \\
(.010)\end{array}$ & $\begin{array}{l}-.200 \\
(.003)\end{array}$ & $\begin{array}{l}-.202 \\
(.003)\end{array}$ \\
\hline Asian & $\begin{array}{l}.0005 \\
(.054)\end{array}$ & $\begin{array}{l}.002 \\
(.054)\end{array}$ & $\begin{array}{l}-.032 \\
(.007)\end{array}$ & $\begin{array}{l}-.016 \\
(.007)\end{array}$ \\
\hline Other race & $\begin{array}{l}-.107 \\
(.018)\end{array}$ & $\begin{array}{l}-.110 \\
(.018)\end{array}$ & $\begin{array}{l}-.151 \\
(.006)\end{array}$ & $\begin{array}{l}-.146 \\
(.006)\end{array}$ \\
\hline \multicolumn{5}{|l|}{ Adult immigrant } \\
\hline Hispanic & $\begin{array}{l}-.254 \\
(.005)\end{array}$ & $\begin{array}{l}-.121 \\
(.011)\end{array}$ & $\begin{array}{l}-.368 \\
(.003)\end{array}$ & $\begin{array}{l}-.167 \\
(.005)\end{array}$ \\
\hline \multicolumn{5}{|l|}{ Non-Hispanic: } \\
\hline White & $\begin{array}{l}.012 \\
(.018)\end{array}$ & $\begin{array}{l}.080 \\
(.019)\end{array}$ & $\begin{array}{l}-.058 \\
(.005)\end{array}$ & $\begin{array}{l}.030 \\
(.005)\end{array}$ \\
\hline Black & $\begin{array}{l}-.193 \\
(.021)\end{array}$ & $\begin{array}{l}-.145 \\
(.021)\end{array}$ & $\begin{array}{l}-.316 \\
(.007)\end{array}$ & $\begin{array}{l}-.258 \\
(.007)\end{array}$ \\
\hline Asian & $\begin{array}{l}-.282 \\
(.013)\end{array}$ & $\begin{array}{l}-.168 \\
(.016)\end{array}$ & $\begin{array}{l}-.177 \\
(.004)\end{array}$ & $\begin{array}{l}-.056 \\
(.005)\end{array}$ \\
\hline Other race & $\begin{array}{l}-.119 \\
(.040)\end{array}$ & $\begin{array}{l}-.021 \\
(.040)\end{array}$ & $\begin{array}{l}-.221 \\
(.016)\end{array}$ & $\begin{array}{l}-.128 \\
(.016)\end{array}$ \\
\hline Controls for English proficiency? & No & Yes & No & Yes \\
\hline
\end{tabular}

Source: 2005-2007 American Community Survey data.

Note: The reported figures are estimated coefficients from least squares regressions, run separately by education category, in which the dependent variable is the natural logarithm of average hourly earnings during the twelve months preceding the survey date. Heteroskedasticity-robust standard errors are shown in parentheses. The sample includes men ages 25-59 who do not reside in institutions and who report average hourly earnings between $\$ 1$ and $\$ 1,000$. The sample sizes are 155,667 for those with less than 12 years of education and 1,647,100 for those with 12 or more years of education. All regressions include controls for age, geographic location, and survey year, and the regressions for those with 12 or more years of education also include dummies identifying individuals with 1315 and 16 or more years of education. Among foreign-born individuals who were not born to an American parent, "child immigrants" are those who arrived in the United States before the age of 16, and "adult immigrants" are those who arrived at age 16 or later. Sampling weights were used in the calculations. 
Table 9: Percentage Distributions and Average Education of U.S. Men, Ages 25-59, by Nativity/Generation and Race/Ethnicity

\section{A. By Nativity/Generation}

U.S.-born:

U.S.-born parents

Mixed nativity parents

Foreign-born parents

Foreign-born:

Born abroad of American parent

Child immigrant

Adult immigrant

All nativity/generation groups

\begin{tabular}{ccccc}
$\begin{array}{c}\text { Percent } \\
\text { of Total }\end{array}$ & & $\begin{array}{c}\text { Sample } \\
\text { Size }\end{array}$ & & $\begin{array}{c}\text { Average } \\
\text { Education }\end{array}$ \\
\cline { 1 - 1 } 74.8 & & & \\
3.0 & & & \\
3.0 & & $8,2103,030$ & & 13.6 \\
& & & 14.0 \\
1.0 & & 3,199 & & 13.7 \\
4.2 & & 10,903 & & 13.9 \\
14.1 & & 38,355 & & 11.9 \\
$100.0 \%$ & & 333,807 & & 13.3
\end{tabular}

\section{B. By Nativity/Generation and Race/Ethnicity}

\section{U.S.-born with U.S.-born parents}

Hispanic

Non-Hispanic:

White

Black

Asian

Other race

All race/ethnic groups

U.S.-born with mixed nativity parents

Hispanic

Non-Hispanic:

White

Black

Asian

Other race

All race/ethnic groups

\section{U.S.-born with foreign-born parents}

Hispanic

Non-Hispanic:

White

Black

Asian

Other race

All race/ethnic groups

\section{Adult immigrant}

Hispanic

Non-Hispanic:

White

Black

Asian

Other race

All race/ethnic groups

4.0

81.6

12.1

0.5

1.8

$100.0 \%$

24.2

65.9

3.2

3.5

3.3

$100.0 \%$

49.7

30.9

4.0

14.9

0.5

$100.0 \%$

53.2

17.1

7.6

21.9

0.3

$100.0 \%$
8,144

12.7

222,715

13.7

23,425

2,079

6,667

263,030

12.9

14.4

12.9

13.6

1,859

13.1

7,291

240

406

420

10,216

14.4

13.6

14.3

13.8

14.0

3,545

12.8

2,987

257

1,252

63

8,104

19,329

7,516

14.3

2,751

13.3

8,601

14.7

158

14.2

38,355
9.7

14.5

14.1

15.1

14.3

13.7

11.9 
Source: 2003-2009 Current Population Survey outgoing rotation group data.

Note: The sample includes men ages 25-59 who do not reside in institutions. Among foreign-born individuals who were not born to an American parent, "child immigrants" are those who arrived in the United States before the age of 16, and "adult immigrants" are those who arrived at age 16 or later. Sampling weights were used in the calculations. 


\section{Table 10: Employment and Wage Regressions}

\begin{tabular}{|c|c|c|c|c|}
\hline \multirow[b]{2}{*}{ Regressor } & \multicolumn{2}{|c|}{ Employment } & \multicolumn{2}{|c|}{ Log Wage } \\
\hline & $(1)$ & $(2)$ & $(1)$ & $(2)$ \\
\hline \multicolumn{5}{|l|}{$\begin{array}{l}\text { U.S.-born: } \\
\text { U.S.-born parents (reference group) }\end{array}$} \\
\hline Mixed nativity parents & $\begin{array}{l}.014 \\
(.004)\end{array}$ & $\begin{array}{l}.008 \\
(.004)\end{array}$ & $\begin{array}{l}.037 \\
(.008)\end{array}$ & $\begin{array}{l}.010 \\
(.007)\end{array}$ \\
\hline Foreign-born parents & $\begin{array}{l}-.009 \\
(.005)\end{array}$ & $\begin{array}{l}-.007 \\
(.005)\end{array}$ & $\begin{array}{l}-.012 \\
(.008)\end{array}$ & $\begin{array}{l}-.009 \\
(.007)\end{array}$ \\
\hline \multicolumn{5}{|l|}{ Foreign-born: } \\
\hline Born abroad of American parent & $\begin{array}{l}.014 \\
(.007)\end{array}$ & $\begin{array}{l}.008 \\
(.007)\end{array}$ & $\begin{array}{l}.010 \\
(.013)\end{array}$ & $\begin{array}{l}-.017 \\
(.012)\end{array}$ \\
\hline Child immigrant & $\begin{array}{l}.006 \\
(.004)\end{array}$ & $\begin{array}{l}.034 \\
(.004)\end{array}$ & $\begin{array}{l}-.155 \\
(.007)\end{array}$ & $\begin{array}{l}-.061 \\
(.006)\end{array}$ \\
\hline \multicolumn{5}{|l|}{ Adult immigrant } \\
\hline $0-10$ years in U.S. & $\begin{array}{l}.012 \\
(.003)\end{array}$ & $\begin{array}{l}.045 \\
(.003)\end{array}$ & $\begin{array}{l}-.294 \\
(.006)\end{array}$ & $\begin{array}{l}-.196 \\
(.006)\end{array}$ \\
\hline Over 10 years in U.S. & $\begin{array}{l}.030 \\
(.003)\end{array}$ & $\begin{array}{l}.069 \\
(.003)\end{array}$ & $\begin{array}{l}-.273 \\
(.006)\end{array}$ & $\begin{array}{l}-.146 \\
(.005)\end{array}$ \\
\hline \multicolumn{5}{|l|}{ Education: } \\
\hline Less than 12 years & & $\begin{array}{l}-.108 \\
(.003)\end{array}$ & & $\begin{array}{l}-.236 \\
(.004)\end{array}$ \\
\hline \multicolumn{5}{|l|}{12 years (reference group) } \\
\hline 13-15 years & & $\begin{array}{l}.041 \\
(.002)\end{array}$ & & $\begin{array}{l}.122 \\
(.003)\end{array}$ \\
\hline 16 or more years & & $\begin{array}{l}.098 \\
(.002)\end{array}$ & & $\begin{array}{l}.492 \\
(.003)\end{array}$ \\
\hline
\end{tabular}

Source: 2003-2009 Current Population Survey outgoing rotation group data.

Note: The reported figures are estimated coefficients from least squares regressions. Heteroskedasticity-robust standard errors are shown in parentheses. The dependent variable for the employment regressions is a dummy identifying individuals who were employed during the CPS survey week. The sample includes men ages 25-59 who do not reside in institutions (see Table 9 for sample sizes). The dependent variable for the wage regressions is the natural logarithm of average hourly earnings. The sample for these regressions is further restricted to employed individuals who report average hourly earnings between $\$ 1$ and $\$ 1,000$. The sample size for the wage regressions is 239,796. All regressions include controls for age, geographic location, and survey month/year. Among foreignborn individuals who were not born to an American parent, "child immigrants" are those who arrived in the United States before the age of 16, and "adult immigrants" are those who arrived at age 16 or later. Sampling weights were used in the calculations. 
Table 11: Employment and Wage Differentials (Relative to U.S.-born, Non-Hispanic Whites with U.S.-Born Parents), by Nativity/Generation and Race/Ethnicity

\begin{tabular}{|c|c|c|c|c|}
\hline \multirow[b]{2}{*}{ Regressor } & \multicolumn{2}{|c|}{ Employment } & \multicolumn{2}{|c|}{ Log Wage } \\
\hline & (1) & (2) & $(1)$ & (2) \\
\hline \multicolumn{5}{|c|}{ U.S.-born with U.S.-born parents } \\
\hline Hispanic & $\begin{array}{l}-.054 \\
(.005)\end{array}$ & $\begin{array}{l}-.026 \\
(.005)\end{array}$ & $\begin{array}{l}-.187 \\
(.008)\end{array}$ & $\begin{array}{l}-.088 \\
(.007)\end{array}$ \\
\hline \multicolumn{5}{|c|}{$\begin{array}{l}\text { Non-Hispanic: } \\
\text { White (reference group) }\end{array}$} \\
\hline Black & $\begin{array}{l}-.149 \\
(.003)\end{array}$ & $\begin{array}{l}-.127 \\
(.003)\end{array}$ & $\begin{array}{l}-.304 \\
(.005)\end{array}$ & $\begin{array}{l}-.229 \\
(.005)\end{array}$ \\
\hline Asian & $\begin{array}{l}.007 \\
(.010)\end{array}$ & $\begin{array}{l}-.003 \\
(.010)\end{array}$ & $\begin{array}{l}-.032 \\
(.019)\end{array}$ & $\begin{array}{l}-.074 \\
(.017)\end{array}$ \\
\hline \multicolumn{5}{|c|}{ U.S.-born with mixed nativity parents } \\
\hline Hispanic & $\begin{array}{l}-.031 \\
(.009)\end{array}$ & $\begin{array}{l}-.012 \\
(.009)\end{array}$ & $\begin{array}{l}-.156 \\
(.017)\end{array}$ & $\begin{array}{l}-.091 \\
(.015)\end{array}$ \\
\hline \multicolumn{5}{|l|}{ Non-Hispanic: } \\
\hline White & $\begin{array}{l}.010 \\
(.005)\end{array}$ & $\begin{array}{l}-.002 \\
(.005)\end{array}$ & $\begin{array}{l}.058 \\
(.009)\end{array}$ & $\begin{array}{l}.015 \\
(.008)\end{array}$ \\
\hline Black & $\begin{array}{l}-.116 \\
(.031)\end{array}$ & $\begin{array}{l}-.112 \\
(.030)\end{array}$ & $\begin{array}{l}-.181 \\
(.050)\end{array}$ & $\begin{array}{l}-.170 \\
(.047)\end{array}$ \\
\hline Asian & $\begin{array}{l}-.027 \\
(.023)\end{array}$ & $\begin{array}{l}-.035 \\
(.022)\end{array}$ & $\begin{array}{l}-.006 \\
(.040)\end{array}$ & $\begin{array}{l}-.042 \\
(.036)\end{array}$ \\
\hline \multicolumn{5}{|c|}{ U.S.-born with foreign-born parents } \\
\hline Hispanic & $\begin{array}{l}-.041 \\
(.007)\end{array}$ & $\begin{array}{l}-.013 \\
(.007)\end{array}$ & $\begin{array}{l}-.187 \\
(.011)\end{array}$ & $\begin{array}{l}-.084 \\
(.010)\end{array}$ \\
\hline \multicolumn{5}{|l|}{ Non-Hispanic: } \\
\hline White & $\begin{array}{l}-.003 \\
(.007)\end{array}$ & $\begin{array}{l}-.015 \\
(.007)\end{array}$ & $\begin{array}{l}.088 \\
(.014)\end{array}$ & $\begin{array}{l}.032 \\
(.013)\end{array}$ \\
\hline Black & $\begin{array}{l}-.186 \\
(.032)\end{array}$ & $\begin{array}{l}-.193 \\
(.031)\end{array}$ & $\begin{array}{l}-.141 \\
(.047)\end{array}$ & $\begin{array}{l}-.189 \\
(.044)\end{array}$ \\
\hline Asian & $\begin{array}{l}-.023 \\
(.012)\end{array}$ & $\begin{array}{l}-.045 \\
(.011)\end{array}$ & $\begin{array}{l}.102 \\
(.022)\end{array}$ & $\begin{array}{l}-.011 \\
(.020)\end{array}$ \\
\hline \multicolumn{5}{|c|}{ Adult immigrant in U.S. over 10 years } \\
\hline Hispanic & $\begin{array}{l}-.003 \\
(.004)\end{array}$ & $\begin{array}{l}.087 \\
(.004)\end{array}$ & $\begin{array}{l}-.516 \\
(.006)\end{array}$ & $\begin{array}{l}-.258 \\
(.006)\end{array}$ \\
\hline \multicolumn{5}{|l|}{ Non-Hispanic: } \\
\hline White & $\begin{array}{l}.022 \\
(.006)\end{array}$ & $\begin{array}{l}.019 \\
(.006)\end{array}$ & $\begin{array}{l}.017 \\
(.013)\end{array}$ & $\begin{array}{l}-.016 \\
(.011)\end{array}$ \\
\hline Black & $\begin{array}{l}-.005 \\
(.010)\end{array}$ & $\begin{array}{l}.009 \\
(.010)\end{array}$ & $\begin{array}{l}-.298 \\
(.019)\end{array}$ & $\begin{array}{l}-.248 \\
(.017)\end{array}$ \\
\hline Asian & $\begin{array}{l}.024 \\
(.005)\end{array}$ & $\begin{array}{l}.020 \\
(.005)\end{array}$ & $\begin{array}{l}-.060 \\
(.013)\end{array}$ & $\begin{array}{l}-.113 \\
(.011)\end{array}$ \\
\hline Controls for education? & No & Yes & No & Yes \\
\hline
\end{tabular}

Source: 2003-2009 Current Population Survey outgoing rotation group data.

Note: The reported figures are estimated coefficients from least squares regressions. Heteroskedasticity-robust standard errors are shown in parentheses. The dependent variable for the employment regressions is a dummy 
identifying individuals who were employed during the CPS survey week. The sample includes men ages 25-59 who do not reside in institutions (see Table 9 for sample sizes). The dependent variable for the wage regressions is the natural logarithm of average hourly earnings. The sample for these regressions is further restricted to employed individuals who report average hourly earnings between $\$ 1$ and $\$ 1,000$. The sample size for the wage regressions is 239,796. All regressions include controls for age, geographic location, and survey month/year. Among foreignborn individuals who were not born to an American parent, "child immigrants" are those who arrived in the United States before the age of 16, and "adult immigrants" are those who arrived at age 16 or later. Sampling weights were used in the calculations. 